\title{
Regulatory Cliff Effects and Systemic Risk*
}

\author{
Andreas Brøgger \\ Graeme Cokayne \\ Copenhagen Business School Danmarks Nationalbank
}

\begin{abstract}
This paper investigates systemic risks arising from regulatory cliff effects. Sudden discrete changes to asset properties, from regulatory cliff effects, cause financial agents to act simultaneously in a homogeneous way, exacerbating systemic risk. We develop a model which quantifies these effects, and find that under certain circumstances, even small changes have drastic consequences. Taking the model to the data, we find that current market measures imply that the circumstances are satisfied for the Danish financial system.
\end{abstract}

JEL classification: G18; G21.

Keywords: Banking; Regulation; Systemic Risk; Fire Sales; Covered Bonds.

${ }^{*}$ The viewpoints and conclusions stated are the responsibility of the individual contributors, and do not necessarily reflect the views of Danmarks Nationalbank.

The authors wish to thank Rasmus Tommerup for the codevelopment of the model and preliminary versions of this paper; Thomas Sangill, Emilio Hellmers, Srdjan Zakula, and Stig Hesselberg for valuable cooperation, suggestions and clarifications on the development of this paper; and Kristian Kristiansen, Søren Korsgaard, Søren Hesel, Christian Bentzen, Mads Harmsen and Oliver Grinderslev for valuable feedback. The authors alone are responsible for any remaining errors. 


\section{Introduction}

Systemic risk in a financial system occurs when losses to a financial institution spreads beyond that institution, causing losses to other financial institutions, potentially causing the system itself to cease functioning efficiently. As the system functions less efficiently losses can spread to the real economy, which can then create a negative feedback loop between the real and financial sectors of the economy (Silva et al., 2016). The financial literature focuses on two distinct channels through which losses to an institution can propagate to other institutions. The first is through the direct linkages with other institutions. I.e. if one institution relies on payments from another institution, losses to the second institution can imperil the cash flows to the first institution. The second channel is through indirect linkages, for example through the effect on asset prices of a fire sale where institutions react to losses by selling assets (Greenwood et al., 2015). In this context, a fire sale is the 'forced' sale of an asset at a dislocated price (Shleifer and Vishny, 2010). This paper concentrates

on the second of those channels to estimate potential vulnerabilities in the Danish financial system.

We identify and estimate systemic risks from regulatory cliff effects in a scenario where Capital Requirements Regulation (CRR) compliant covered bonds lose their regulatory benefits. Using an extension of the model of Greenwood et al. (2015), we examine how regulatory cliff effects would cause banks' solvency to fall and, as banks attempt to return to their initial solvency, induce a fire sale. Prior to this article, the Greenwood et al. model has not to our knowledge been used to estimate a fire sale resulting from a regulatory cliff effect.

In general, banking regulations have been put in place to avert financial crises occurring by reducing liquidity and credit risks, i.e. the direct linkages channel of systemic risk. However, in cases of extreme financial distress, breaching the regulations might have drastic effects on the financial system (Cruz Lopez et al., 2013), 
so-called "cliff effects", whereby the regulatory consequences of a measure crossing a threshold causes a violent reaction in the financial markets. For example, price declines could be exacerbated by market participants seeking to sell assets to meet liquidity requirements (Gorton, 2009). Alternatively, the demand for collateral could cause an increase in premiums for high-quality assets, creating a cliff effect for borderline assets that might lose their high-quality status during financial downturns (IMF, 2012). Thus, while regulations might reduce the chance of a financial crisis, they can add to systemic risk in times when their requirements are breached.

In our analysis we look at the cliff effect of covered bonds losing their CRR compliance. For a covered bond to be CRR compliant, each loan behind the bond must fulfill certain loan-to-value requirements on an ongoing basis. These requirements make the bond safer than non-compliant covered bonds and thus entail regulatory benefits for the holders of these covered bonds. The loss of this status would then cause a loss of these regulatory benefits. We consider three regulatory channels through which the loss of CRR compliance of covered bonds can affect banks. The first is through an increase in risk weights that reduces the banks' solvency, which might lead the banks to sell covered bonds to regain solvency. The second channel is through the inclusion of more exposures to the issuing bank in calculations for large exposure regulations, possibly breaching those regulations and requiring the bank to sell covered bonds. The final channel is through the Liquidity Coverage Ratio (LCR), where the liquidity haircut attached to covered bonds might increase if their ratings decrease. This could breach the LCR requirement and require the bank to sell covered bonds to regain more liquid assets. For these reasons, the loss of CRR compliance for covered bonds can lead to a regulatory cliff effect where a broad range of banks seek to sell covered bonds at the same time.

The literature on fire sales in finance began with research into the liquidation value of collateral in the late 1980s (Shleifer and Vishny, 2010). Since then a signif- 
icant body of literature has been built (see for example Cecchetti et al., 2016; Dow and Han, 2015; Caballero and Simsek, 2013; Bindseil, 2013). In the initial models, the liquidation value of collateral was taken as exogenous (see for example Hart and Moore, 1994, 1995, 1998). While treating the value of the asset to be sold as exogenous might often be reasonable, this is less likely to be the case if the potential buyers of the asset are constrained in some way. One way in which they might be constrained is if the potential buyers are facing similar restricting conditions to those of a firm forced to sell the asset. The model of Greenwood et al. (2015) provides a straightforward procedure to estimate how fire sales of assets might lead to losses in the financial system. Falls in asset prices lead to an increase in the leverage of the banks holding those assets, which in turn leads those banks to sell assets to return to their previous leverage levels. This fire sale of assets leads to a further fall in prices. The Federal Reserve Bank of New York has since used the model to estimate systemic risk in the US (Duarte and Eisenbach, 2015).

The model in this paper differs from the model by Greenwood et al. (2015) as in our case the fire sales are initiated by a regulatory cliff effect. Therefore, the first price fall in our model is an endogenous fire sale effect rather than an exogenous shock to asset prices, as per Greenwood et al. (2015). After the fall in prices of covered bonds decreases the banks' solvency, we extend the original model by allowing banks to again sell to increase their solvency to desired levels, precipitating another round of price falls, and so on.

To further ground the model, we estimate the effects on the Danish covered bond market. This market can exemplify the model as the value of Danish covered bonds is around 1.5 times the Danish GDP, making them an important segment of the financial market. Since 2007, Danish law has allowed banks to issue CRR compliant covered bonds $(\mathrm{SDOs})^{1}$, which now account for 83 per cent of the covered bond

\footnotetext{
${ }^{1}$ In Denmark CRR compliant Danish covered bonds are referred to as scrligt dakkede obligationer (SDO) or særligt dakkede realkredit obligationer (SDRO), while ordinary non-CRR compliant
} 
market. Not only are they a significant share of the market but the concentration of issuers of covered bonds is very high, with three institutions covering more than 80 per cent of the market. Furthermore, a large share of the bonds, over one fourth, is owned by Danish banks. Hence, the loss of CRR compliance would reduce most banks' solvency and so a broad range of banks might, at the same time, sell their covered bonds. Hence, a loss of CRR compliance for an institution's bonds is likely to have a large impact on the Danish financial sector. Furthermore, we cover a large portion of the market by focusing on the reactions of the largest investor type. The data set we use for this is unique, as it spans the entire network of covered bonds in the Danish financial system, including details on issuers and owners of the bonds.

As yet no Danish financial institution has lost CRR compliance for its covered bonds. The most likely avenue for the possibility of loss of CRR compliance is through a significant fall in house prices. If house prices were to fall by 20 per cent across the country, various of the issuing institutions would be required to supply significant additional collateral to maintain the CRR compliance of their covered bonds (Danmarks Nationalbank, Half). If they could not do so their covered bond issuances might lose their CRR compliance. For comparison, house prices fell by 18.3 per cent between their peak in 2007 and trough in $2009,{ }^{2}$ and so this is not an unlikely scenario.

Section II describes the regulatory cliff effects and Section III details the model to be used. Section IV outlines the data. The results are given in Section V with a discussion of robustness in Section VI and conclusions in Section VII.

Danish covered bonds are referred to as realkreditobligationer (RO). In this paper SDO refers to SDO's as well as SDRO's.

${ }^{2}$ According to the House Price Index of Statistics Denmark. 


\section{Regulatory cliff effects}

The cliff effects in this model arise because CRR compliance (SDO status) for a bond entails requirements for the security behind the bond, which, when broken, worsen the regulatory conditions for the bond holders. ${ }^{3}$ In the case of Danish covered bonds, to be CRR compliant, Loan-to-Value (LTV) limits must be fulfilled on an ongoing basis for each individual loan behind the bonds. For a housing loan, the LTV limit is 80 per cent, ${ }^{4}$ which means that the credit institution must immediately pledge additional capital if the market value of the home declines to the point that the LTV limit is breached. Therefore, if house prices were to fall significantly, the LTV limits might be breached, and hence the related bonds would lose their special status. The loss of their special status would mean that the bonds would revert to become traditional non-CRR compliant covered bonds, which, under CRR, would mean that they would be considered to be no different to any other unsecured debt. The change in status affects bond holders through three main channels, namely: the effect on risk weights; the effect on large-exposure regulations; and, possibly, through effects on the LCR. The three channels will now be analysed in more depth.

\section{Effect on risk weights}

A bond's loss of CRR compliance will cause banks' solvency to decrease. The requirement for CRR compliance tends to ensure that bonds meeting those requirements are safer than those that do not. Therefore, bonds not meeting the CRR requirements tend to have higher risk weights in banks' risk-weighted assets than compliant bonds. ${ }^{5}$ The loss of CRR compliance would then increase the risk weights

\footnotetext{
${ }^{3}$ According to CRR Article 129.

${ }^{4}$ Note that the LTV limit is $60-70$ per cent for commercial property.

${ }^{5}$ In Denmark, until 2007, only ROs were issued and they had a risk weight of 10 per cent. After 2007 all bonds issued had to be CRR compliant to get the 10 per cent risk weight, though bonds issued before 2007 were 'grandfathered' to maintain the 10 per cent risk weight. ROs without the grandfathering have a risk weight of 50 per cent using the standard method on the banking book.
} 
of those bonds that lost their compliant status, and hence increase the holding banks' risk-weighted assets, thereby reducing those banks' solvency. To return to their previous levels of solvency, the banks would then need to hold more capital or liquidate assets. As will be discussed in Subsection VI.4, the main way in which banks could liquidate assets of this size quickly would be to sell off their bonds.

Given an initial risk weight of $R W_{0}$, an ordinary bond risk weight of $R W_{1}$ and the value of a bank's CRR compliant covered bond exposure of $Q_{S D O}$, a loss of CRR compliance would lead to an increase in risk-weighted assets (RWA) of

$$
\Delta \mathrm{RWA}=\left(R W_{1}-R W_{0}\right) \cdot Q_{S D O}
$$

A $R W_{0}$ of 10 per cent and a $R W_{1}$ of 35 per cent is used for Danish banks' holdings of Danish covered bonds. ${ }^{6}$ For a covered bond exposure of $€ 4 \mathrm{bn}$, this would lead to a $\Delta$ RWA of $€ 1 \mathrm{bn}$. The original solvency of the bank is

$$
\text { Solvency }=\frac{C E T_{0}}{R W A_{0}}
$$

and the change in solvency is

$$
\Delta \text { Solvency }=\frac{-C E T_{0} \cdot \Delta R W A}{R W A_{0} \cdot\left(R W A_{0}+\Delta R W A\right)} .
$$

Continuing the previous example, given further original RWA of $€ 10 \mathrm{bn}$ and a solvency of 15 per cent, the loss of CRR compliance would lead to a decrease in solvency of 1.4 percentage points.

See Section II.1

${ }^{6} R W_{0}$ and $R W_{1}$ will depend on the issuance and issuer ratings, the banks' allocation of the assets between their trading and banking book, and which risk weight method the bank uses. For more on which riskweight is appropriate, see Subsection II.1. 


\section{Effect on large exposures}

A second way in which the loss of CRR compliance for bonds would affect banks that hold these assets is through large-exposure regulations. CRR Article 395 forbids banks to take on any counterparty exposures exceeding 25 per cent of the bank's capital. However, while CRR compliant bonds are fully exempted from this regulation according to the Danish Financial Supervisory Authority's decision on CRR Article 400, only half of the value of non-compliant bonds is exempted according to CRR Article 402. If CRR compliant bonds were to lose their CRR compliant status they would be included in these calculations, potentially breaching the largeexposure regulations. If the regulations were breached, the banks would have to sell off their bonds until they were again in compliance with the regulation, unless they had other ways of reducing their relevant exposure or quickly increasing their capital. The exact value of the bonds required to be sold would depend on the individual bank's exposures.

\section{Effect on liquidity coverage ratio}

A third way in which the loss of the CRR compliant status might affect holding banks is through LCR regulations. Broadly speaking, the regulation requires banks to have liquid assets to cover 100 per cent of the next month's payments in a predefined stress scenario. The size of a bank's liquid assets, taking into account liquidity haircuts, depends, in part, on the rating of those assets. If bonds were to lose their special status, it is possible that this would lead to a downgrade in their rating. If such a rating downgrade caused the holding banks to breach their LCR requirements, then these banks would likely need to convert these bonds into more

liquid assets by selling them. It should be noted that a loss of CRR compliance will not in itself affect the LCR requirements. The LCR requirements will only come into play if the loss of compliance leads to a ratings downgrade. 
As an example, a covered bond with a rating of AAA has a liquidity haircut $(\mathrm{H})$ of 7 per cent, while an A-rated covered bond has a haircut of 15 per cent. ${ }^{7}$ This would mean that if a bank has an LCR of 100 (i.e. the value of the bank's liquid assets, after haircuts, is equal to its stressed monthly outflows), where 50 per cent is made up of covered bonds, and a stressed monthly outflow (MO) of $€ 2 \mathrm{bn}$, a downgrade from AAA to A would lead to a change in the LCR of

$$
\begin{aligned}
\Delta \mathrm{LCR} & =-\left(H_{1}-H_{0}\right) \cdot \frac{Q_{S D O}}{M O}, \\
& =-(15 \%-7 \%) \cdot \frac{1 b}{2 b}, \\
& =-4 \% .
\end{aligned}
$$

The LCR would therefore fall to 96, which is below the requirement.

\section{II.1. Other factors}

Other important factors that determine the size of the cliff effects are described in detail below. These factors interact with each other and so should not be viewed in isolation. For example, when considering the consequences for a loss of CRR compliance for banks who use the standard method versus the consequences for the banks who use an internal ratings-based method for calculating the risk weights for their covered bonds, one needs to consider whether it is for the banking book or the trading book. In all cases we see the cliff effects being present, but in varying strengths.

\section{II.1.1. Banks owning their own bonds}

In the Danish financial system, a financial group can consist of different financial institutions, for example a mortgage bank and a commercial bank. While the finan-

\footnotetext{
${ }^{7}$ See Danmarks Nationalbank, Financial Stability, 2nd Half 2014.
} 
cial institutions within the same group are treated as separate legal and commercial entities, special regulations apply to trade conducted within the group. For example, Danish commercial banks often buy the covered bonds issued by the mortgage banks within their group. These covered bonds will largely be exempted from the regulations outlined previously. For example, these covered bonds attract no risk weights in the risk-weighted assets of the holding banks on the group level. Therefore, it would not affect the bank's solvency on the group level if these bonds lost their CRR compliance, and so would not lead the bank to start a fire sale. Nonetheless, the banks would suffer second-round effects if other banks sold their covered bonds, as the price of the bonds would fall, leading to a fall in the value of the bank's assets and hence equity. These equity losses might then lead banks to join subsequent rounds of fire sales.

\section{II.1.2. Banking book vs. trading book}

Another factor that can affect the risk weights of the covered bonds is whether banks record them in their banking book or trading book. Bonds recorded in banks' banking books are intended to be held until maturity while those recorded in their trading books are bought with the intention of being sold. From the banks' perspective the relative risks accorded to the bonds, based on the purpose of their purchase, are different. The risks associated with those in the banking book tend to be more focused on the probability of default, while the risks of those in the trading book relate more to the market risk of the bond and hence to the volatility of their prices.

According to our liaison with Danish banks, in general, the result of these differences in risks is that covered bonds recorded in the trading book will attract a lower risk weight (both before and after any loss of CRR compliance) and have a lower relative difference in risk weights between CRR compliant bonds and non-compliant covered bonds, than those in the banking book. Therefore, the more CRR compliant 
covered bonds a bank holds in its trading book, the smaller the effect will be of a loss of CRR compliance. In our analysis, we use a change in risk weights of 10 per cent to 35 per cent with the loss of CRR compliance. This implicitly assumes that banks have 50 per cent of their CRR compliant bonds recorded in their trading book and 50 per cent in their banking book, as well as a change in risk weights on the trading book of 10 to 20 per cent and in the banking book of 10 to 50 per cent. We have used these shares as they generally align with reports from Danish banks.

\section{II.1.3. Standard method vs. internal ratings-based method}

To calculate risk weights for assets, banks can use one of two methods. The first is the standard method and the other is the internal ratings-based method (IRB). Under the standard method, banks use risk weights derived, amongst other things, from ratings provided by external credit rating agencies. In contrast, the IRB method allows banks to use their own estimated risk parameters to calculate the appropriate risk weights. To use the IRB method, banks need to meet certain minimum conditions and disclosure requirements, and gain approval from their national supervisor.

The usage of standard method vs. internal ratings-based method, could hence influence the risk weights assigned to the covered bonds. In the numbers provided in Section II.1.2 we have taken the banks' risk weighting approach into account.

\section{II.1.4. Issuance rating vs. issuer rating}

To calculate the risk weight for non-CRR compliant covered bonds in the banking book, one needs to know which rating is the appropriate one to use. Under CRR regulation, when a bond is CRR compliant it follows Table 1 dependent on its rating. However, when a covered bond is no longer CRR compliant it is to be treated as a general exposure to an institution, and thus follows Table 2 based on the institution's

rating. Further, if the institution is unrated it follows Table 3 based on the rating 
of the issuing institution's country. In Denmark, the typical bond issuance rating is AAA, yielding a risk weight of 10 per cent for CRR compliant bonds, while the typical rating for issuers is A, giving a risk weight of 50 per cent for non-compliant covered bonds. ${ }^{8}$ No issuers are unrated. The following tables are from CRR Article 129,120 and 121 respectively.

Table 1: Risk weights for CRR compliant covered bonds

\begin{tabular}{ccccccc}
\hline Issuance Rating (S\&P) & AAA/AA & A & BBB & BB & B & C/R/D \\
Risk weight (\%) & 10 & 20 & 20 & 50 & 50 & 100
\end{tabular}

Table 2: Risk weights for exposures to rated institutions

\begin{tabular}{ccccccc}
\hline Issuer Rating (S\&P) & AAA/AA & A & BBB & BB & B & C/R/D \\
Risk weight (\%) & 20 & 50 & 50 & 100 & 100 & 150
\end{tabular}

Table 3: Risk weights for exposures to unrated institutions

\begin{tabular}{ccccccc}
\hline Country Rating (S\&P) & AAA/AA & A & BBB & BB & B & C/R/D \\
Risk weight $(\%)$ & 20 & 50 & 100 & 100 & 100 & 150
\end{tabular}

\section{Model}

In our model, following the loss of CRR compliance, banks react to changes in their solvency level. ${ }^{9}$ In the baseline scenario, the banks are assumed to want to keep their solvency constant by selling assets. We focus on changes in solvency due to changes in risk weights because it can be shown that by keeping their solvency constant, given the shock, they also maintain their required LCR and large exposure

\footnotetext{
${ }^{8}$ According to Danske Bank Markets' Nordic Covered Bond Handbook. Available at: http://danskeanalyse.danskebank.dk/abo/NordicCoveredBondHandbook2016/\$file/ NordicCoveredBondHandbook_2016.pdf. [Accessed 14 March 2016].

${ }^{9}$ As the holdings of more investor types are included in our data, they could be included in the model with a seperate reaction function for each type of investor. In this version the focus is on the reaction of the banks. However, in further scenarios the reactions of pension and investment funds could be developed.
} 
limits. However, when this assumption is relaxed, large exposures might eventually become the binding constraint.

We calculate the effects of the regulatory cliff effects using the model shown in the graphical representation in Figure 1. The model is shocked exogenously by the loss of the preferential treatment of the CRR-compliant covered bonds, which increases the risk weights (RW) for the banks holding these assets. This increase in risk weights increases the banks' risk-weighted assets (RWA) and lowers their solvency below their initial level $\left(S<S_{0}\right)$. In response to the decrease in solvency, banks sell assets (and pay off debt), to return to their original solvency. ${ }^{10}$ We assume that banks are not able to raise new capital. These sales reduce the banks' risk-weighted assets but also cause the prices (P) of the banks' assets to fall. The size of the price impact depends on each asset's liquidity and the amount sold. Banks holding the fire-sold assets suffer spillover losses, which lowers their asset valuation (A), reserve equity (E) and solvency (S). These spillover losses come as an addition to the direct losses. If the final solvency level is lower than the original solvency $\left(S<S_{0}\right)$, the banks will engage in a further round of fire sales. This process continues until either the solvency is back to the original level, the banks run out of assets or the amount wanting to be sold by the banks is below some effort threshold. ${ }^{11}$

The rest of the section describes the mechanics of the reaction function and the price function.

\section{III.1. Reaction function}

There are two causes which lead banks to sell assets in our model, and the consequences of each are derived separately below. First, the consequences of a change in risk weights, without a price change, are derived, and secondly, the consequences of price change, without a risk weight change, are derived. Once banks know by how

\footnotetext{
${ }^{10}$ See Section VI.5 for an analysis of the relaxation of this assumption.

${ }^{11}$ The effort threshold is in our model set to the value of 1 DKK across all sellers.
} 


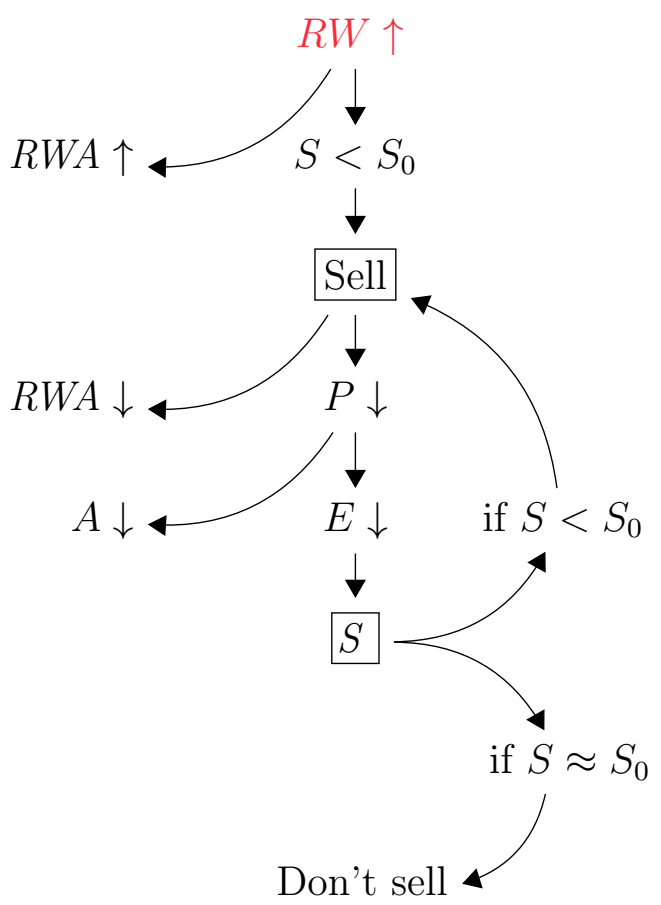

Figure 1: Flow diagram of model. The red variable indicates where the system is shocked.

much to adjust their assets to return to their solvency level, they will choose which assets to sell from their covered bond positions. In the model description below period 0 is the initial position; during period 1 , the CRR compliant bonds lose their CRR compliance; the initial sales occur during period 2; at the start of period 3 the prices change based on the initial sales leading to a fall in solvency, and then the first round of fire sales occur during this period.

\section{Sales purely from a change to risk weights}

The initial solvency is

$$
\text { Solvency } y_{0}=\frac{C E T_{0}}{R W A_{0}}
$$


where $C E T_{0}$ is the common equity tier 1 , and $R W A_{0}$ is the initial risk-weighted assets. Given an increase in risk weights (RW) from period 0 to 1 , the solvency after the change in risk weights is

$$
\text { Solvency } y_{1}=\frac{C E T_{0}}{R W A_{0}+\Delta R W A_{1}}
$$

and

$$
\Delta R W A_{1}=\left(R W_{1}-R W_{0}\right) \cdot \text { Exposure }_{0},
$$

where $R W_{1}$ and $R W_{0}$ are the risk weights of the bonds after and before the loss of CRR compliant status respectively, and Exposure Ex $_{0}$ is the value of bonds losing their CRR compliance.

We now consider two scenarios, derived from different solvency targeting assumptions.

(a) If banks sell after the shock to return to initial solvency ratio, $\frac{C E T_{0}}{R W A_{0}}$, the following must hold

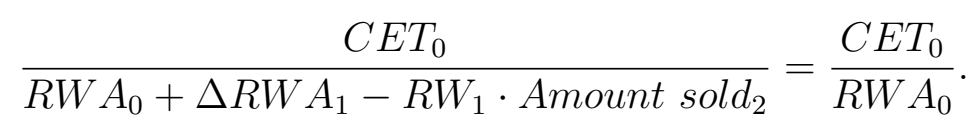

For the equation to balance it must be the case that

$$
\Delta R W A_{1}=R W_{1} \cdot \text { Amount sold } .
$$

Then we insert Equation 7 into Equation 9 and rearrange to find

$$
\text { Amount } \text { sold }_{2}=\frac{R W_{1}-R W_{0}}{R W_{1}} \text { Exposure }_{0}
$$


This means that for a $R W_{0}$ of 10 per cent and a $R W_{1}$ of 35 per cent and an Exposure $_{0}$ of $€ 1 \mathrm{bn}, € 714 \mathrm{~m}$ would be sold, or equivalently 71 per cent of the exposure.

(b) If instead we consider that banks sell after the shock to return to a minimum solvency ratio, $S_{\min }=\frac{C E T_{\min }}{R W A_{0}}$, we get

$$
\frac{C E T_{0}}{R W A_{0}+\Delta R W A_{1}-R W_{1} \cdot \text { Amount sold } 2}=\frac{C E T_{\text {min }}}{R W A_{0}} .
$$

Similar to before, we now insert Equation 7 into Equation 11 and rearrange to find

$$
\begin{aligned}
\text { Amount sold }_{2}= & \frac{R W_{1}-R W_{0}}{R W_{1}} \text { Exposure }_{0} \\
& -\frac{R W A_{0}}{R W_{1}}\left(\frac{C E T_{0}}{C E T_{\min }}-1\right) \cdot 12
\end{aligned}
$$

The first expression on the right hand side of this equation is the amount sold if the bank wants to return to its previous solvency. The second term, therefore, shows how much less the bank needs to sell if it has a buffer of equity. This term is proportional to the size of the buffer relative to the minimum solvency level, and inversely proportional to the risk weight of the sold asset.

\section{Sales purely from a change in prices}

Following the initial sales due to the change in risk weights, the prices of the assets will fall. This will lead to a loss for the banks holding the covered bonds, which will cause the banks' solvency to fall, leading them to further rounds of sales. These later rounds of sales are the fire sales that we are analysing.

\footnotetext{
${ }^{12}$ In the model only positive values for Amount sold are included.
} 
Given the solvency targeting setup, we know that

$$
\text { Solvency } y_{2}=\text { Solvency }_{0}
$$

and

$$
\text { Solvency } y_{0}=\frac{C E T_{0}}{R W A_{0}}
$$

Now given a decrease in price, $\Delta$ Price $_{3}$, from period 2 to 3 , the solvency after the change in price is

$$
\text { Solvency }_{3}=\frac{C E T_{0}-\operatorname{Loss}_{3}}{R W A_{0}-R W_{1} \cdot \operatorname{Loss}_{3}},{ }^{13}
$$

where the loss is

$$
\text { Loss }_{3}=\Delta \text { Price }_{3} \cdot \text { Exposure }_{0} .
$$

As banks sell to return to their initial solvency ratio, we have that

$$
\frac{C E T_{0}-\text { Loss }_{3}}{R W A_{0}-R W_{1} \cdot \text { Loss }_{3}-R W_{1} \cdot \text { Amount sold }_{3}}=\frac{C E T_{0}}{R W A_{0}} .
$$

Finally, we rearrange and cancel terms to find ${ }^{14}$

$$
\text { Amount } \text { sold }_{3}=\frac{R W A_{0}}{C E T_{0}} \frac{\operatorname{Los}_{3}}{R W_{1}}-\operatorname{Loss}_{3} \text {. }
$$

In general, we would expect that the amount sold will increase with the loss, which, as Equation 16 shows, is equal to the bank's exposure times the price

\footnotetext{
${ }^{13}$ In practice the Loss in the numerator will be larger than the Loss in the denominator, as the risk weight will not fall on the banks' ownership of their own bonds. This distinction is included in the model, but, for the sake of simplicity, not in this example.

${ }^{14}$ The result is for the simple case where everything sold has $R W_{1}$, and that all the losses are given on covered bonds.
} 
change. Therefore, we expect that the fire sales will be greater; the lower the initial solvency is, the lower the final risk weight of the covered bonds is, the greater the bank's exposure to the bonds is, and the greater the price sensitivity of the bonds is.

\section{III.1.1. Explosive fire sales}

Fire sales occur when banks are forced to sell bonds at a dislocated price. Sometimes, however, the fire sale will become an explosive fire sale. Here we define an explosive fire sale as one in which sales in subsequent rounds are larger than those

in previous rounds, leading to ever increasing sales until all sellable assets are sold. Our simulations show that, in general, if sales in any one round are larger than those in the previous round, this will hold for all rounds until they run out of sellable assets. An explosive fire sale will then be the result. Using a simplified example, we determine the conditions under which an explosive fire sale is likely to occur.

For there to be explosive fire sales we need the sales in the next round to be larger than the sales given in the current round

$$
\text { Sales }_{t+1}>\text { Sales }_{t}
$$

or

$$
\frac{\text { Sales }_{t+1}}{\text { Sales }_{t}}>1
$$

Sales for an individual bank $i$ from a capital loss, is given by Equation 18 as

$$
\text { Sales }_{i, t+1}=\frac{R W A_{i, t}}{C E T_{i, t}} \frac{\operatorname{Loss}_{i, t}}{R W_{k}}-\operatorname{Loss}_{i, t}
$$

where $R W A$ and $C E T$ are the risk-weighted assets and common equity tier 1 before the Loss, and $R W_{k}$ is the risk weight of the asset sold.

If we treat the system as a single bank, total sales are calculated by aggregating 
the individual banks' sales

$$
\text { Sales }_{t+1}=\sum_{i} \text { Sales }_{i, t+1}=\sum_{i} \frac{R W A_{i, t}}{C E T_{i, t}} \frac{\operatorname{Loss}_{i, t}}{R W_{k}}-\sum_{i} \operatorname{Loss}_{i, t}
$$

and, since we treat the system as a single bank, we can take the inverse solvency as the equity weighted average value of the market,

$$
\text { Sales }_{t+1}=\overline{\left(\frac{R W A_{t}}{C E T_{t}}\right)} \frac{\sum_{i} \operatorname{Loss}_{i, t}}{R W_{k}}-\sum_{i} \operatorname{Loss}_{i, t} .
$$

Capital losses are given by

$$
\text { Loss }_{t}=\sum_{i} \text { Loss }_{i, t}=\text { Sales }_{t} \cdot P I \cdot \text { Exposure }_{t-1}
$$

where Sales $_{t}$ and Exposure Ex-1 $_{1}$ are the aggregated values, and where $P I$ is the price impact $\frac{\Delta P}{\text { Sales }}$.

By combining Equations 22 and 24 we get

$$
\text { Sales }_{t+1}=\overline{\left(\frac{R W A_{t}}{C E T_{t}}\right)} \frac{\text { Sales }_{t} \cdot P I \cdot \text { Exposure }_{t-1}}{R W_{k}}-\text { Sales }_{t} \cdot P I \cdot \text { Exposure }_{t-1} .
$$

We divide both sides by Sales

$$
\frac{\text { Sales }_{t+1}}{\text { Sales }_{t}}=\overline{\left(\frac{R W A_{t}}{C E T_{t}}\right)} \frac{P I \cdot \text { Exposure }_{t-1}}{R W_{k}}-P I \cdot \text { Exposure }_{t-1}>1,
$$

where the last inequality is known from Equation 20.

Rearranging we get

$$
P I>\left[\text { Exposure }_{t-1}\left(\overline{\left(\frac{R W A_{t}}{C E T_{t}}\right)} \frac{1}{R W_{k}}-1\right)\right]^{-1} .
$$


So, if

$$
P I>P I_{\text {lim }} \equiv\left[\text { Exposure }_{t-1}\left(\overline{\left(\frac{R W A_{t}}{C E T_{t}}\right)} \frac{1}{R W_{k}}-1\right)\right]^{-1}
$$

there will be increasing sales.

We see from Equation 28 that $P I_{\text {lim }}$ is decreasing in Exposure Ex $_{\text {, but increasing }}$ in solvency and the risk weight of the sold asset. So the larger the exposures in the system, the lower the equity weighted average solvency and the lower the risk weight of the sold asset, the lower the limit will be for increasing sales and explosive fire sales.

In a Danish context, this value of $P I_{\text {lim }}$ can now be estimated for the first round. Looking at the exposure data for July 2015 and the balance sheet data for June 2015 we see that Exposure $_{0}=712$ billion DKK, $\overline{\left(\frac{R W A_{t}}{C E T_{t}}\right)}=6.6$ and $R W_{k}=35$ per cent. Plugging this in we find $P I_{\text {lim }}$ to be

$$
\begin{aligned}
P I_{\text {lim }} & =\left[712 \cdot 10^{9} \cdot\left(\frac{6.6}{0.35}-1\right)\right]^{-1} \\
& =7.9 \cdot 10^{-14} \\
& =\mathbf{0 . 7 9} \text { basis points per billion DKK. }{ }^{15}
\end{aligned}
$$

While this derivation shows the price impact, above which we would expect explosive fire sales to occur, this assumes that the market is made up of a single bank, which has the characteristics of the weighted average of the market. In reality, the banks are not identical to the "average bank", and so we would expect that banks will enter into explosive fire sales at different price impacts. The banks entering at

\footnotetext{
${ }^{15}$ Please note that this is not a change in the yield, it is a change in the price. So the price would be 99.9921 if the price was 100 before the sale of 1 bn DKK.
} 
lower price impacts will tend to be those with a greater exposure or a lower solvency. Therefore, for the market as a whole we could expect explosive fire sales to begin to occur at lower price impacts than those shown here.

\section{III.2. Price function}

For the results shown, a simple price function is used. With this price function the price effect is

$$
\Delta P=P I \cdot \text { Sales }
$$

The bonds sold by the banks are treated as the same asset and so have a single uniquely defined price impact, $P I$, in Equation 30. This price impact is then multiplied by the value in DKK of the bonds sold, Sales, to calculate the overall price effect.

This price function is equivalent to Greenwood et al. (2015), had their model contained just a single asset. However, it is relatively easy to introduce cross-asset effects in our model. This is done by creating a matrix of price impacts for the bonds according to the type of bond, the issuer and the maturity, $\overline{\overline{P I}}$, and then multiplying by a vector of assets sold, Sāles, as per

$$
\Delta \bar{P}=\overline{\overline{P I}} \cdot \text { Sales }
$$

While the more complex model might appear more realistic, determining the cross-asset multipliers is not a trivial task and the results may not be greatly different to those of the simple model, especially for a general shock as in this analysis. 


\section{Data}

To examine the model more closely, we use data on the Danish covered bond market. Our focus in this paper is on the banks' balance sheets and their exposures to the Danish covered bond market, as we are investigating the effects of CRR compliant covered bonds losing their compliance. In this section we describe the covered bond market back to 2006 using quarterly data. Amongst the balance sheet variables, the Common Equity Tier 1 (CET1) is generally used as equity. The only exception being when comparing back in time, as CET1 was introduced in 2014. Instead, we here use the accounting equity to make it more comparable. Whilst in the data section all data is for the accounting quarters, the July exposures are used for the results, as we thereby reduce quarter-year effects. The results use 2015 data for 21 of the largest domestic banks, unless otherwise stated. Balance sheet variables were obtained from the Danish Financial Supervisory Authority and banks' portfolios of Danish covered bonds were obtained from VP Securities, a Danish central securities depository. These data form a complete dataset of the domestic covered bond market that has not before been used to measure the fire sale effects from the loss of CRR compliance.

The covered bond market in Denmark is a large and important part of the Danish financial sector. In December 2015, the value of outstanding covered bonds in Denmark was 2,876 billion DKK, or about 1.5 times Danish nominal GDP. While the size of the market has stayed at around 1.5 times Danish GDP since 2009, there has been a significant shift in the composition of the market in recent years. SDOs and SDROs were first issued in 2007 and have since that time steadily increased their share of the market to around 80 per cent of all covered bonds (Figure 2).

Danish covered bonds are mostly held by Danish banks, pension and insurance

funds, and investment funds. In December 2015, Danish banks held around 30 per cent of all covered bonds, while the combined holdings of pension and insurance 


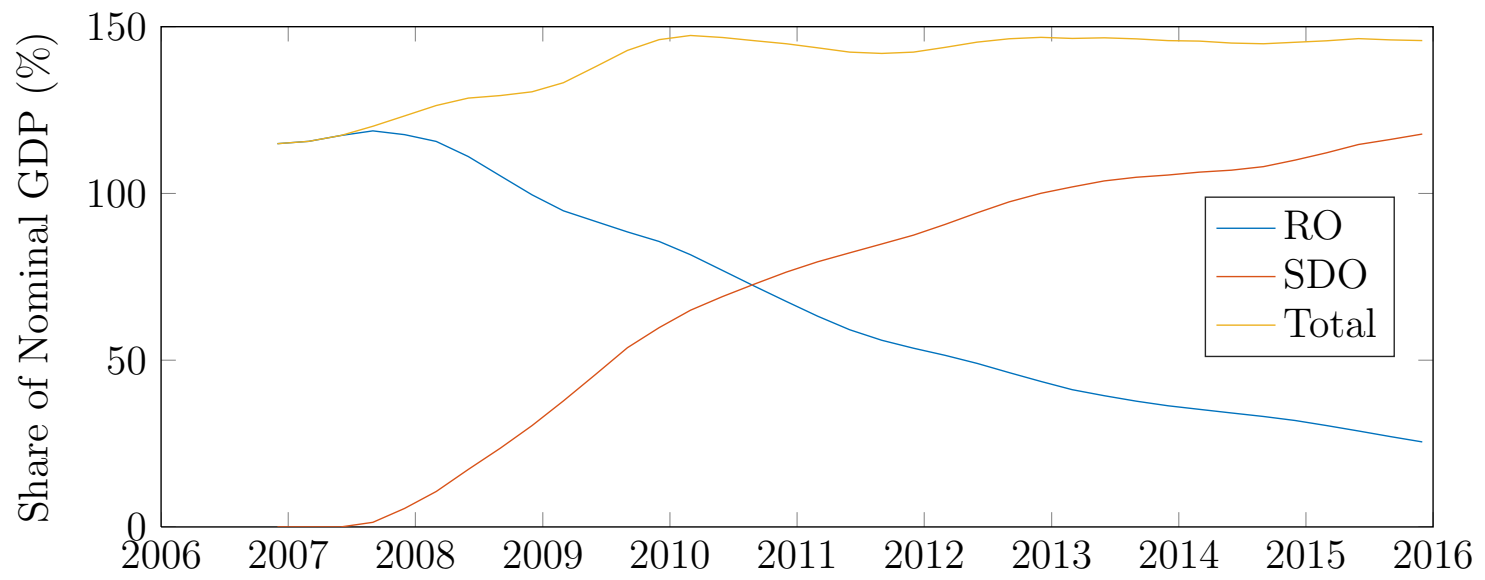

Figure 2: Danish covered bonds with CRR compliance (SDO) have gained market share over the traditional covered bonds (RO) since their introduction in 2007, and now constitute around 80 per cent of all covered bonds. Yearly moving average used.

Table 4: Holder concentration (Ownership share of holders)

\begin{tabular}{lllll} 
Top 10 & Next 40 & Next 250 & Next 1,000 & $\begin{array}{l}\text { Rest } \\
(>10,000)\end{array}$ \\
\hline $32 \%$ & $26 \%$ & $16 \%$ & $3 \%$ & $24 \%$
\end{tabular}

Note: The concentration could be higher, as we are not able to see individual foreign investors. This means all foreign holdings have been included in the Rest category, even though large shares of the covered bonds may be held by a few foreign investors. Additionally, many of the large institutions will themselves be connected in the same financial group.

funds and investment companies were around 40 per cent (Figure 3).

While most covered bonds are held by Danish institutions, over the past six years foreign institutions have increasingly entered the market. The share of Danish covered bonds held by foreign institutions has doubled from around 10 per cent of the market in 2010 to around 20 per cent in 2015 (Figure 3).

While there are many small holders of Danish covered bonds, the market is heavily weighted towards the largest investors. The top 10 investors own nearly a third of the value of the market, and the largest 50 investors own more than half of the market (Table 4). In contrast, the remaining 43 per cent of the market is owned by over 11,250 investors.

The issuer side of the market is also highly concentrated. Five issuers of covered 


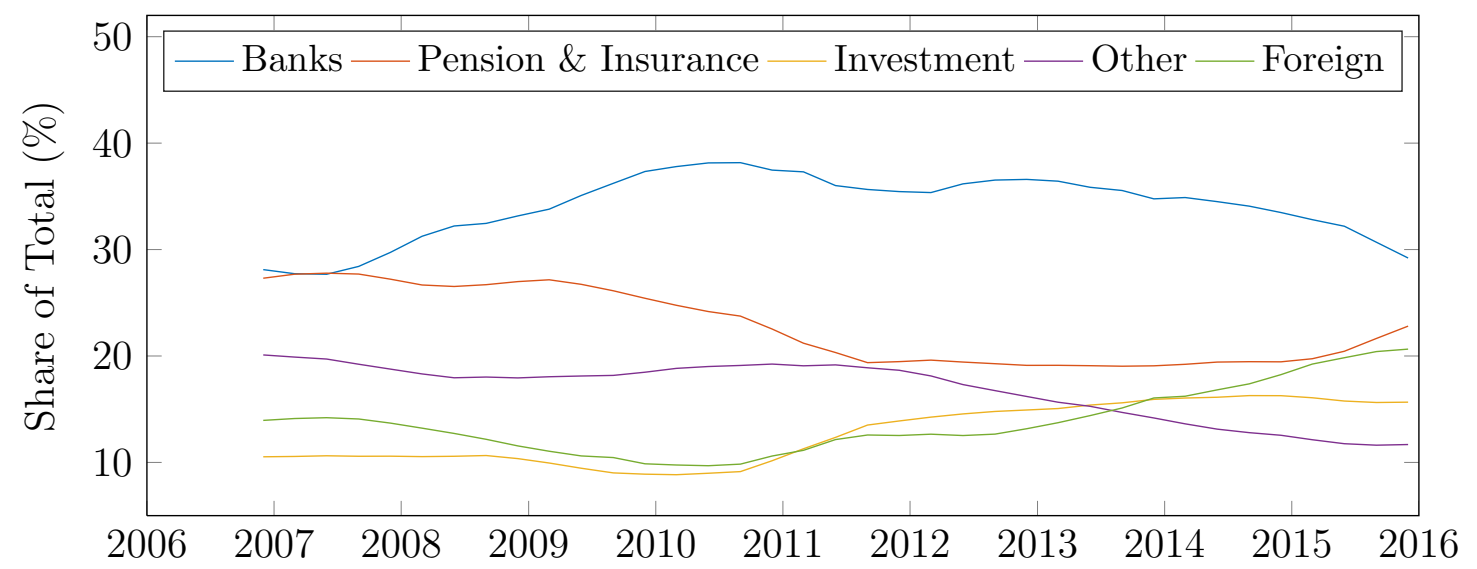

Figure 3: The distribution of Danish covered bonds by holder types has remained fairly constant since 2006, with foreign companies and investment funds taking some bonds from the pension \& insurance funds. Throughout the period banks have been the largest holder, with a current ownership of around 30 per cent. Other owners currently make up only around 10 per cent, indicating that most holders are institutional investors. Yearly moving average used.

bonds account for around 95 per cent of the market (Figure 4). The two largest issuers, Nykredit and Realkredit Danmark, alone represent around two thirds of the market. Furthermore, the market is becoming more concentrated with the share of issuers outside the top 5 decreasing from around 10 per cent of the market in 2007 to around 5 per cent in 2015. Therefore, even if only one of the main issuers' SDOs were to lose their CRR compliance, it would transform a large segment of the market from SDOs to traditional ROs.

Covered bonds account for a significant share of Danish banks' assets. For the systemically important financial institutions (SIFIs), covered bonds account for 16 per cent of their assets, while for the smaller banks they are a slightly higher share at around 18 per cent (Table 5).

Danish banks' solvency rates (Common equity tier 1 divided by risk-weighted assets) are around 15 per cent, on average well in excess of the minimum requirements.

While the market for covered bonds is highly concentrated, the largest holders of covered bonds own a significant amount of bonds from most of the major issuers (Figure 5). So if any one of the issuers were to lose CRR compliance for their covered 


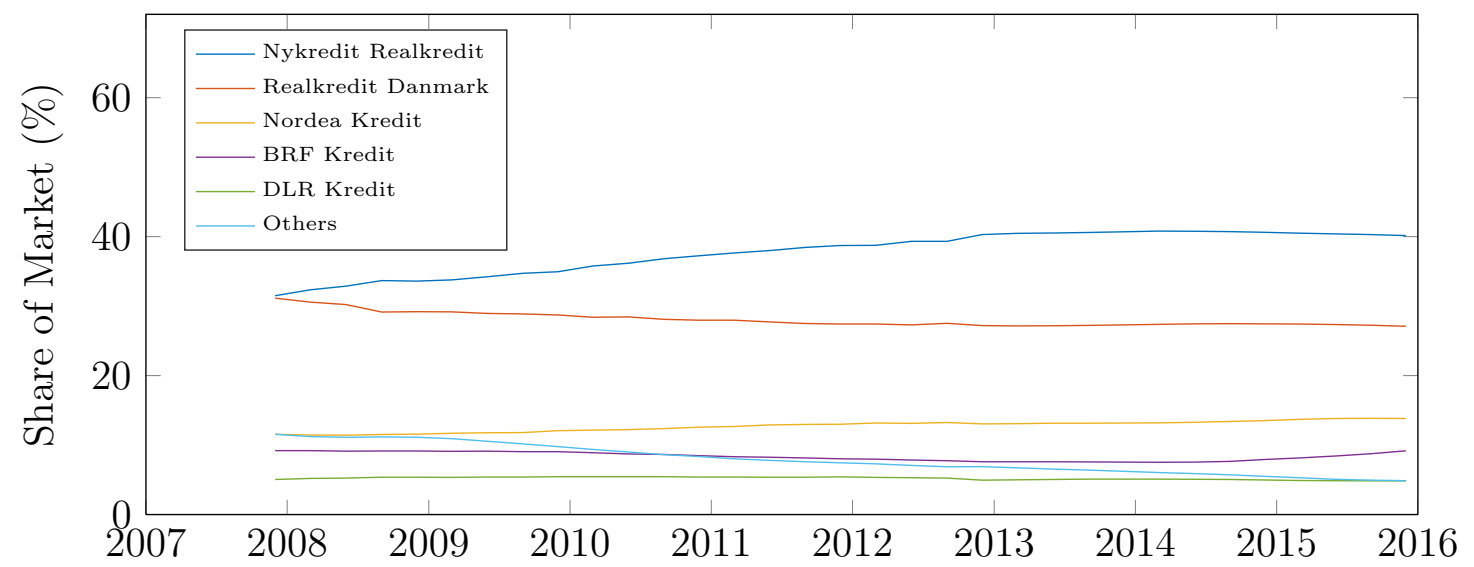

Figure 4: The issuance share of Danish covered bonds has remained fairly constant since 2007 with Nykredit taking some market share from the other issuers. Nykredit is now by far the largest issuer with around 40 per cent of all issuances. The issuances are concentrated on five issuers, which are the only mortgage banks that have issued more than 1 per cent. The smallest is DLR Kredit with around 5 per cent of the issuances. Yearly moving average used.

Table 5: Bank statistics

\begin{tabular}{lrr} 
& SIFI & Non-SIFI \\
\hline Covered Bonds/Assets & $16 \%$ & $18 \%$ \\
Leverage (Assets/CET1), Median & 20 & 11 \\
10th percentile & 14 & 6 \\
90th percentile & 24 & 17 \\
Solvency (CET1/RWA) & $15 \%$ & $16 \%$
\end{tabular}

Note: Values are averages, unless otherwise stated. 


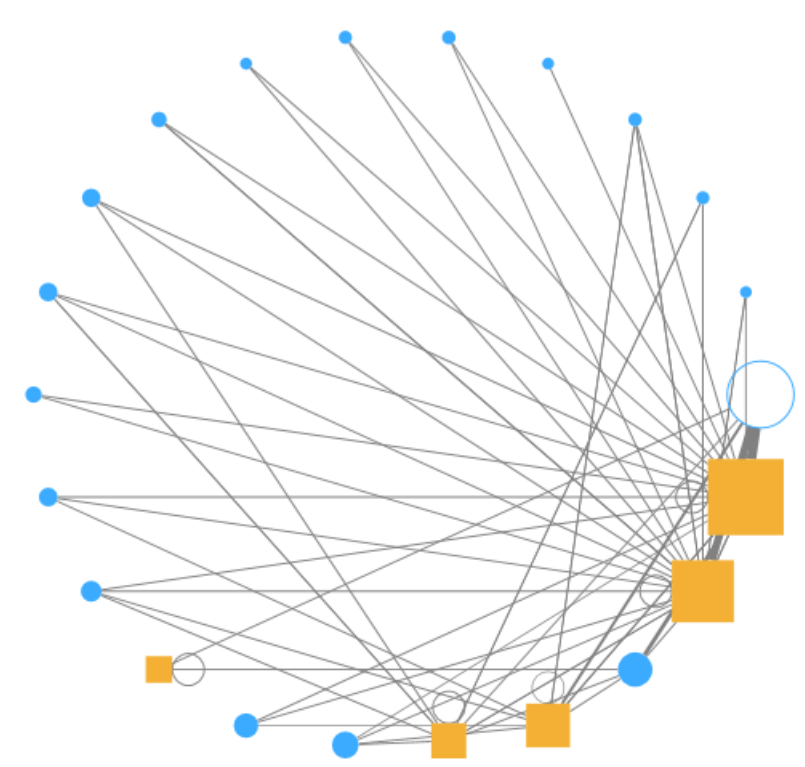

Figure 5: Direct interconnectedness through all Danish covered bond types. The squares are individual bond issuers and the filled circles are individual bond holders. The blue empty circle is a group of all international holders. The size of the nodes indicate amount issued or held. The lines represent exposures between institutions and the thickness of the lines represents the size of the exposure. For the issuers, the grey line in a circle represents ownership of own bonds, which are shown as the average self-ownership across issuing institutions to avoid disclosing confidential information. Only the 22 largest issuers and holders are shown and only the exposures over 0.25 per cent of the market are included. The exposures are at the institutional rather than group level. Separate holders of the same investment fund have been grouped.

bonds, this would affect a broad cross-section of Danish banks.

\section{Results}

We categorise the results into two effects. The regulatory solvency loss as the direct effect, and the equity loss from the following sales as the fire sale effect. This split between the two effects is somewhat unrealistic as there are likely to be price falls in response to the loss of CRR compliance regardless of whether banks attempt to return to their previous solvency levels. The loss of CRR compliance is likely to be interpreted as a signal that the covered bonds are more risky than previously estimated. The greater level of perceived riskiness will normally lead to a fall in 
price. Nonetheless, in this model we separate the two effects, so that we can analyse them individually.

In the baseline scenario we estimate the two effects when assuming a price impact of 0.13 basis points per billion DKK of sales (in line with the price impact in Greenwood et al. (2015)) and banks attempting to return to the previous level of solvency, and varying the shock from no shock to one in which CRR compliant covered bonds from all issuers lose their compliance, i.e. 100 per cent.

Later we consider the effects of scenarios with stronger price impacts, and find that new dynamics develop increasing the system equity lost in a faster than linear way to, in some cases, 100 per cent. In the Discussion section, we investigate the robustness of the model regarding its assumptions.

\section{V.1. Baseline scenario}

\section{V.1.1. Direct effect}

The direct effect on banks' solvency is linearly related to the size of the shock (Figure 6). Here the shock size is defined as the share of CRR compliant covered bonds that lose their compliance. If all CRR compliant covered bonds lose their compliance the solvency of the system will be reduced by 0.7 percentage points.

It should be noted that in our analysis we have allowed the shock size to take on any value between 0 per cent and 100 per cent of CRR compliant covered bonds. In practice this will probably not be the case, as certain discrete values will be more likely. This is due to CRR compliance being determined for each capital center within the issuing institution. To defend their covered bonds' CRR compliance, issuing institutions can shift capital between capital centers. Therefore, it is likely that if an issuing institution were to lose their CRR compliance, this will only occur after it has used up all possible internal transfers of capital and so it will lose CRR compliance for all of its covered bonds at the same time. Therefore, the shape 


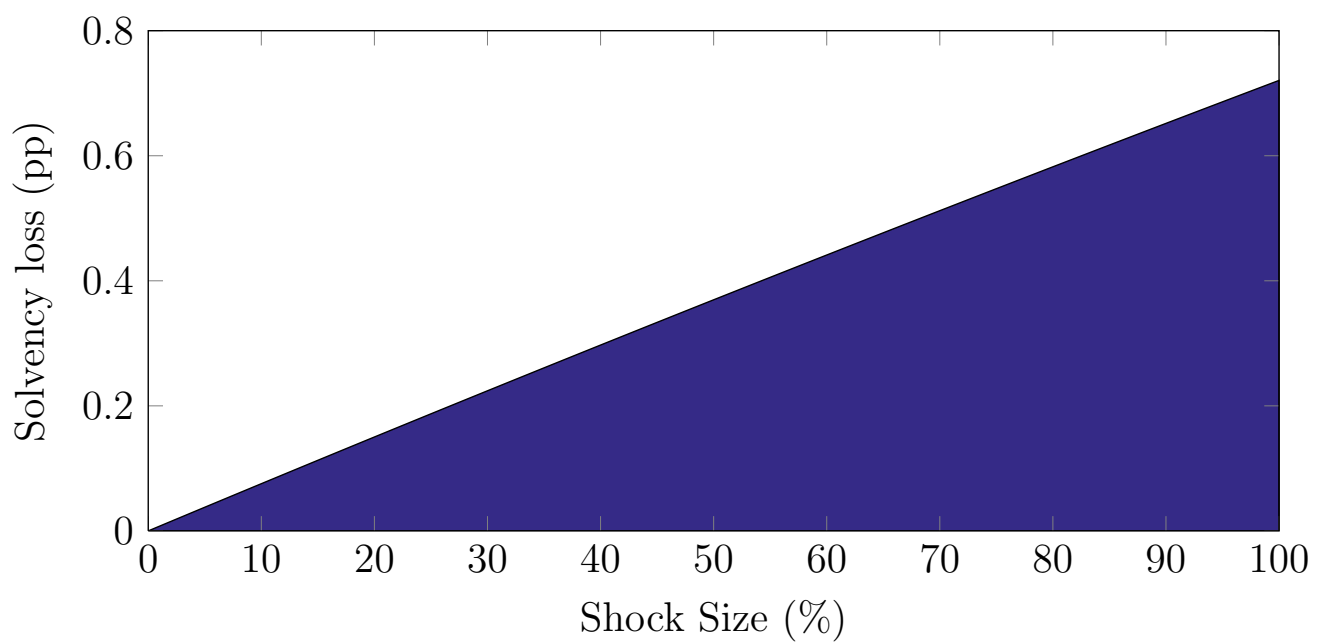

Figure 6: Solvency loss vs. shock size. Shock size is defined as the share of CRR compliant covered bonds that lose their compliance.

depicted in Figure 6 is likely to be discontinuous in shock size and jump up as each issuing institution progressively loses its CRR compliance for all of its covered bonds. As the shock progressively gets larger, it is not necessarily the case that the loss of CRR compliance will begin with the smallest institution and move to the larger institutions. Therefore, we make no assumption about the discontinuous nature of the shock but instead present the results as if the shock is continuous. As an example the smallest issuer has 5 per cent of the market and the largest has 40 per cent.

Additionally, in the case of falling house prices, it is likely that the shock size itself will not increase linearly, but at some points actually faster. In the beginning, as house prices fall, no institutions will lose their CRR compliance for their covered bonds, as they have enough spare equity to inject in their capital centers if needed. Then, at some point, the first institution will lose its compliance for its covered bonds. This is likely to be at a time when other institutions are close to losing their own CRR compliance, as the institutions in general have similar exposures and are well diversified. On top of that the loss of one institution's compliance of its bonds may, in itself, increase the likelihood of other institutions losing their CRR compliance, as the other institutions own the bonds from the first institution. It is 


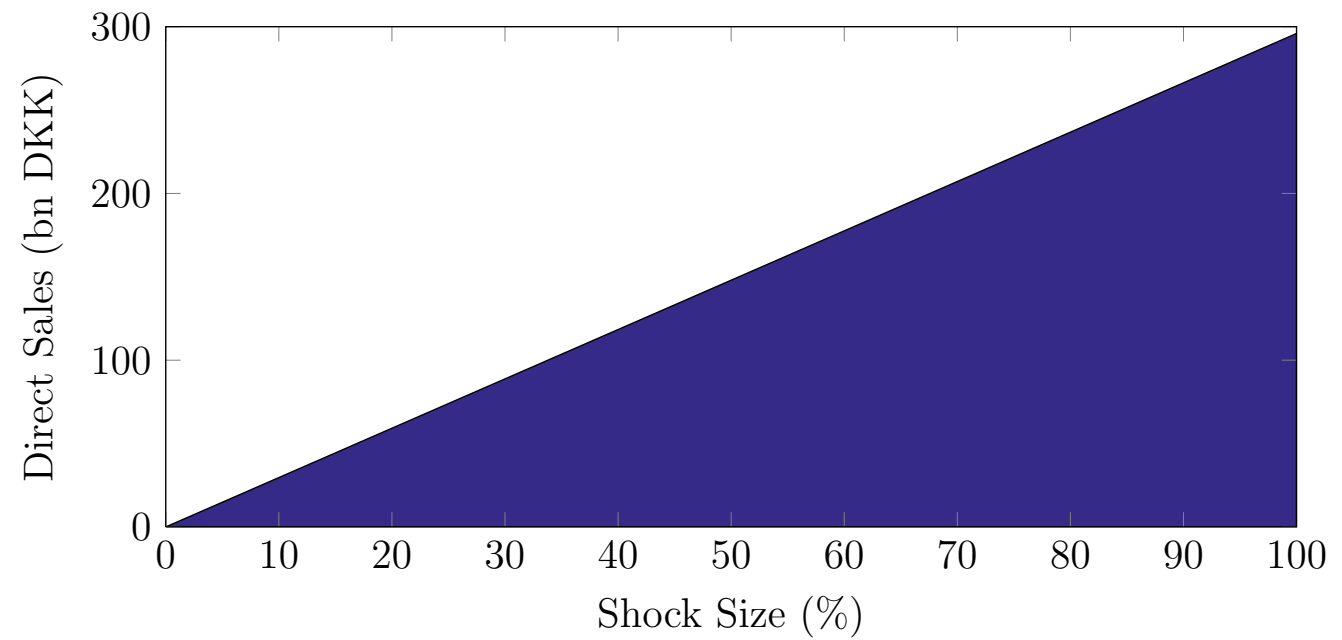

Figure 7: Direct sales vs. shock size. The sales in this figure only include the first round sales in response to the changing risk weights and not the fire sales which come in later rounds.

therefore likely that, as house prices fall, there will be no immediate loss of CRR compliance, but once institutions start losing their compliance, it will happen at an increasing pace, leading to a non-linear effect in the evolution of the shock size.

\section{V.1.2. Fire sales}

Similar to the solvency loss, the direct sales that will be entered into, given our assumptions of the banks' reactions to the direct effect, is a linear function of the size of the shock (Figure 7). If all CRR compliant covered bonds lose their compliance, then banks will initially sell around 300 billion DKK worth of covered bonds.

The price of bonds will fall in response to the initial sales. This will lead to further rounds of sales and equity losses. In the baseline scenario shown in Figure 8, the share of system equity lost increases practically linearly with the size of the shock. At the baseline scenario with the price impact of Greenwood et al. (2015), as the shock increases, the system equity lost rises to 1 per cent of total equity. This loss reflects the total sales, which rise to a high of around 350 billion DKK (Figure 9).

However, if the price impact increases above the Greenwood et al. (2015) level the 


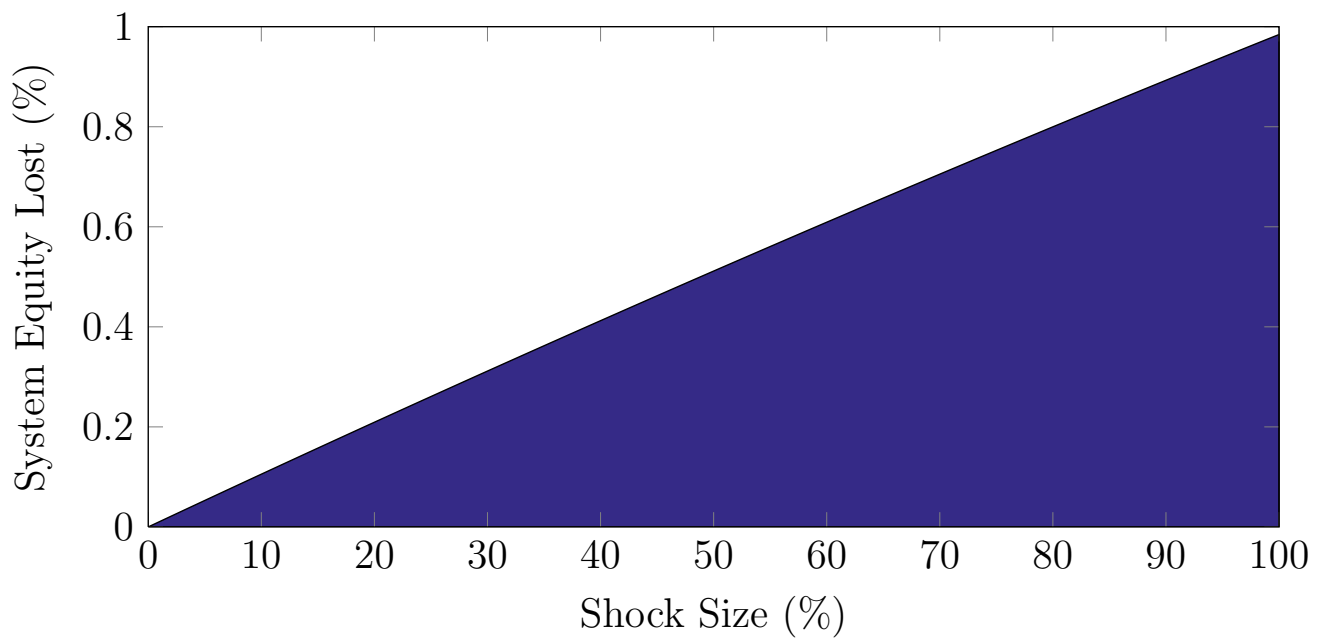

Figure 8: System equity lost as a result of fire sales, given different shares of CRR compliant covered bonds losing their compliance.

system equity lost rapidly reaches 100 per cent of the total system equity (Figure 10), regardless of the size of the shock. This shows that if the price impact is above a certain level, and banks attempt to return to their previous solvency levels, explosive fire sales are almost inevitable.

In our model, banks do not enter the sales at separate times, but at the same time due to being affected by the same shock. Because the size of the price falls will be related to the overall volume of sales, the banks will suffer greater equity losses than if they were the only bank trying to sell covered bonds. In practice, it may seem irrational that banks would join in such a sale. However, regardless of how many other banks are attempting to sell bonds it is always in the individual bank's interest to sell its bonds.

\section{V.2. Stronger price impact scenarios}

As the price impact increases from the Greenwood et al. (2015) level, there is a linear relationship between the increase in the price impact and the increase in the share of system equity lost. However, once the price impact reaches a critical level, 


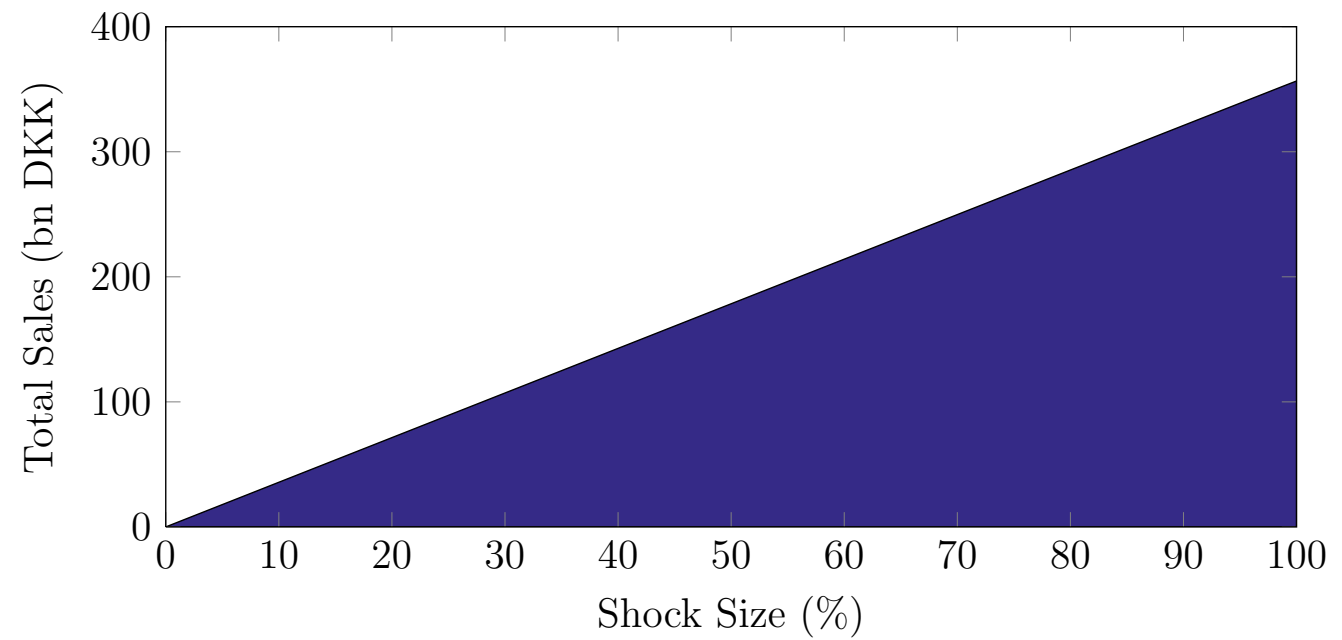

Figure 9: Size of total sales given different shares of CRR compliant covered bonds losing their compliance.

explosive fire sales begin, leading to a sudden disproportional increase in the system equity lost (Figure 11). For our case this is especially visible for small shocks. This disproportional increase in the equity loss is clearly due to the explosive fire sales, as we see a large spike in the number of rounds of fire sales that the banks engage in at that critical price level, indicating that even a small initial shock starts a fire sale which leads to new larger sales, and that this does not stop until all bonds are sold (Figure 12).

At even higher levels of the price impact, as the banks run out of additional covered bonds to sell, these explosive fire sale effects matter less and the system equity lost increases almost linearly again until the entire system equity is lost (Figure 11 and 13). ${ }^{16}$

\footnotetext{
${ }^{16}$ The loss of the entire system's equity could be caused by a haircut on covered bonds of just over 31 per cent, based on the median SIFIs' covered bond exposures. From Table 5 we see that the median bank owns assets worth 20 times its equity value (a leverage of 20), and that it has 16 per cent of its assets in covered bonds. This means that the median bank has a covered bond exposure of 3.2 times its equity value. Therefore a haircut of just over 31 per cent would cause a total loss of equity for this bank. This, however, is a much larger haircut than has been seen before. In the previous crisis the haircut was 6.7 per cent., calculated as the peak to trough fall in the Nykredit realkreditindex (19 Aug - 28 Oct 2008). Available at: https://www.nykredit.dk/ marketsdk/info/nykreditindeks.xml. [Accessed 22 June 2017].
} 


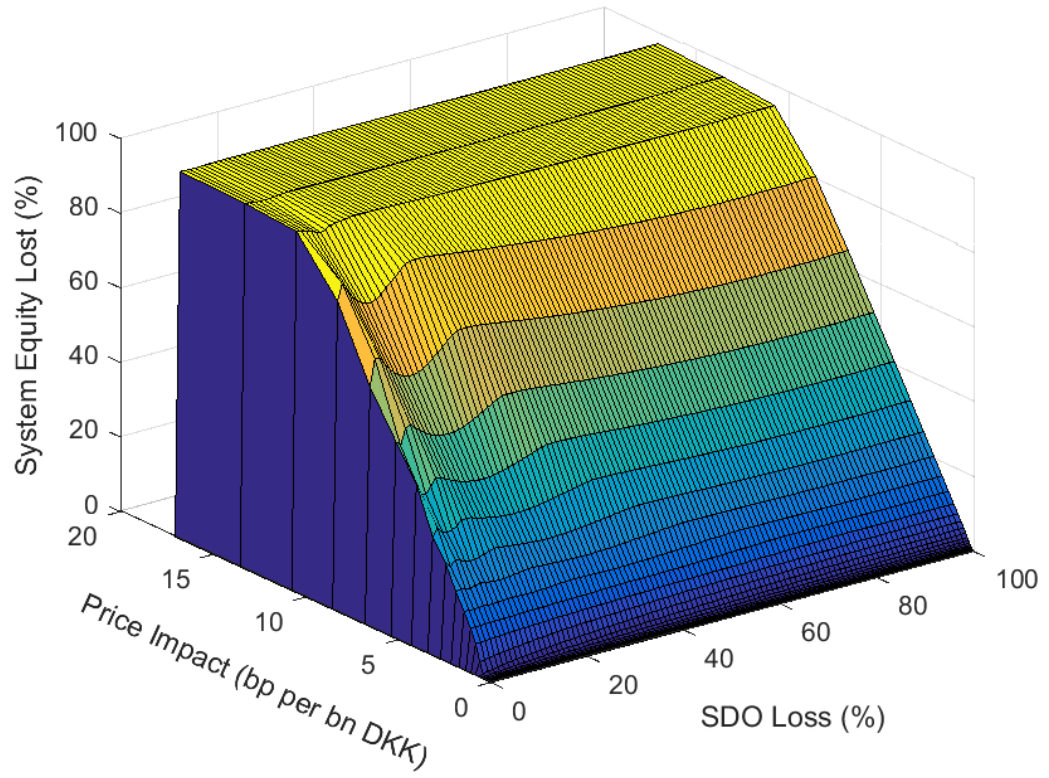

Figure 10: Losses from varying shock size (SDO loss) and price impact, showing that, above a minimum price impact, explosive fire sales are almost independent of shock size. The contours in system equity lost, for specific price impacts, arise from the timing of the fire sales. When a higher proportion of the bonds are being sold at the same time, the final equity lost for the sector will be higher, compared to a case where the bonds are sold more separately. This is because in the second case more of the losses will be taken by the new holders outside of the included banks. At price impacts of 12 bp per bn DKK or higher the system equity lost is 100 per cent for any shock size.

Figure 14 shows that as the shock size is increased, the non-linear effects in the relationship between the price impact and the system equity lost become less dominating. This is because, due to large shocks and higher levels of the price impact, the covered bond sales will be high from the start leading to a quick halt of the explosive fire sales, as banks run out of covered bonds to sell. With smaller shocks but higher price impacts, it is the later rounds of sales that cause the large loss of equity.

What this analysis shows is that, at certain price impacts, even a small shock to CRR compliant covered bonds in Denmark could lead to explosive fire sales. While the direct effect of the loss of compliance is proportional to the size of the shock, it is the reaction to the direct effect that leads to the potentially large indirect effect. Ultimately, the stronger price impacts mean that banks could end up losing their 


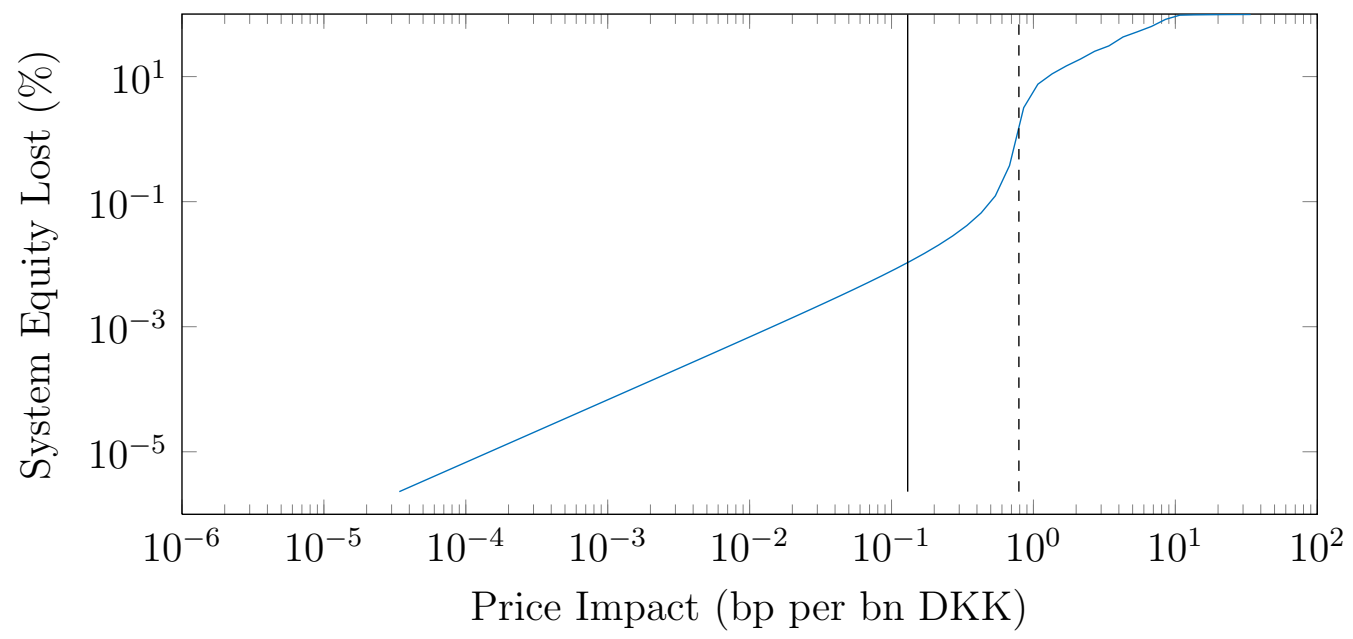

Figure 11: Log scale plot of system equity lost from a small shock vs. price impacts. The dashed vertical line indicates the limit of fire sales calculated in the Model section. The full line indicates the baseline value.

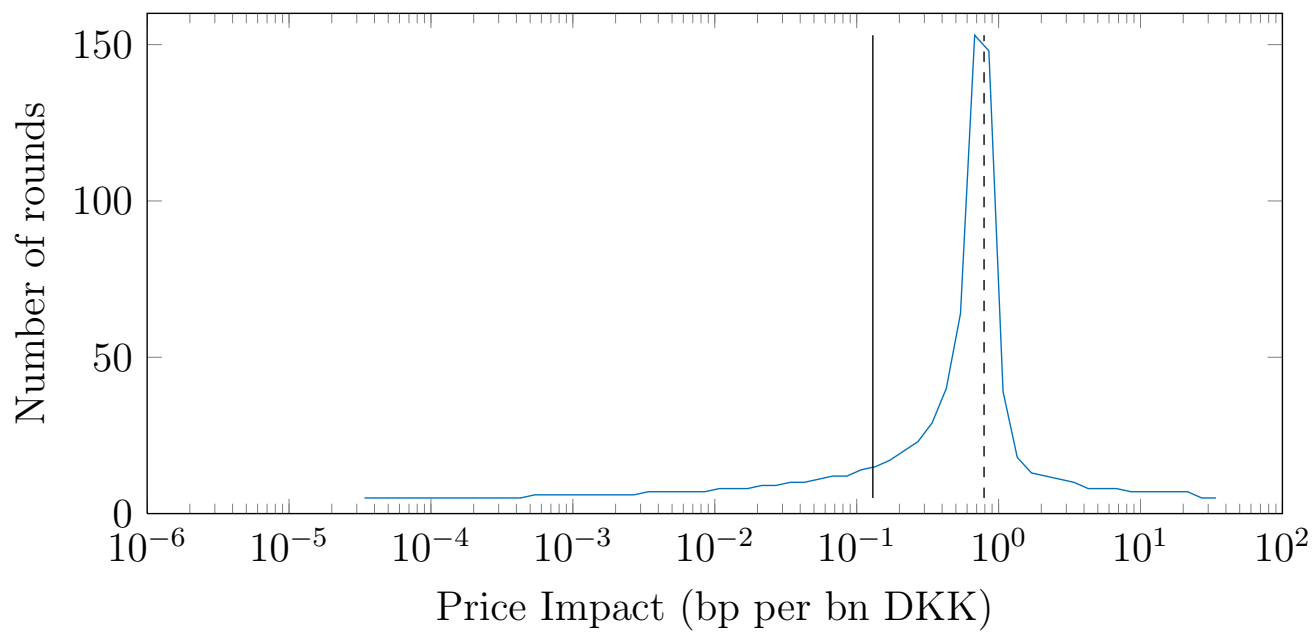

Figure 12: Number of rounds of fire sales from a small shock vs. price impact on a log scale. The dashed vertical line indicates the limit of fire sales calculated in the Model section. The full line indicates the baseline value. 


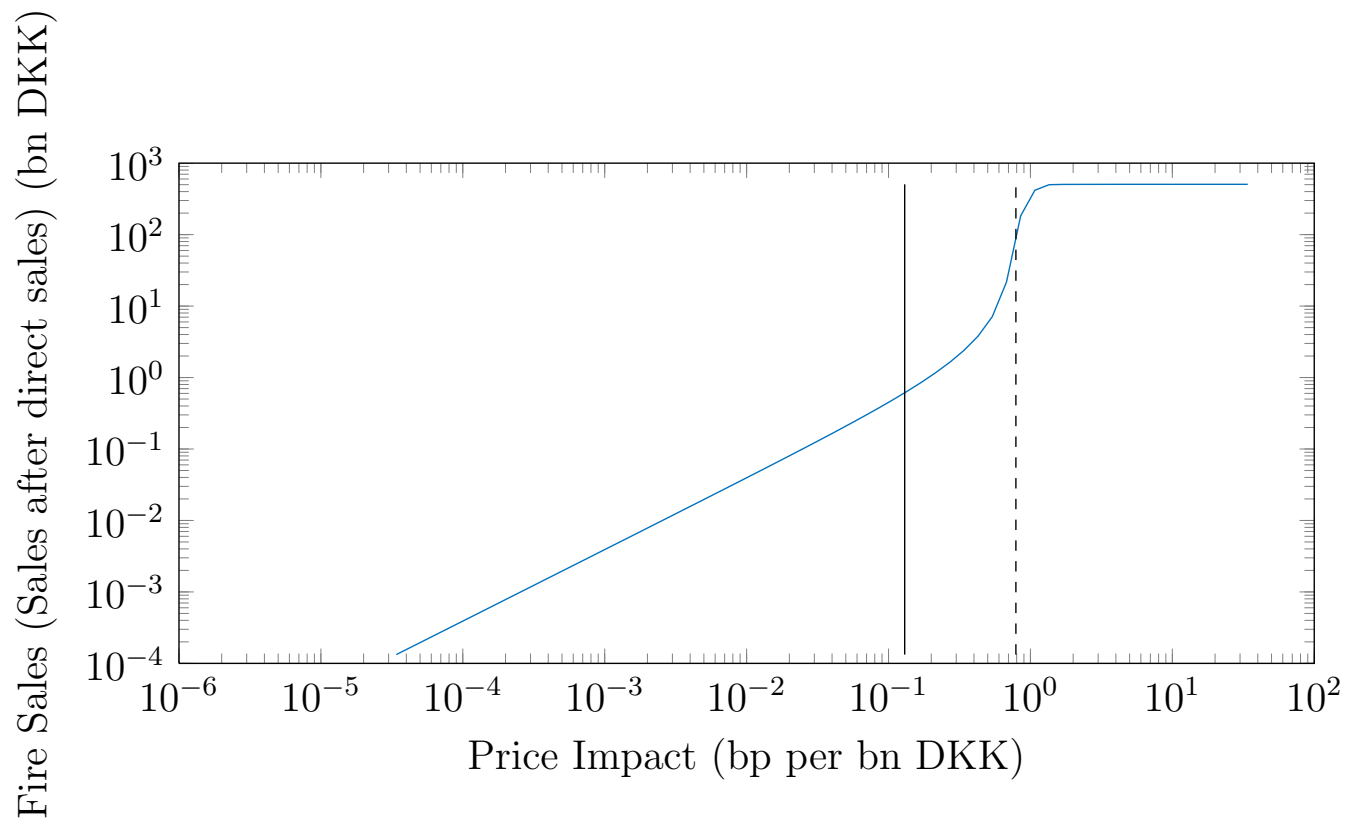

Figure 13: Log scale plot of fire sales from a small shock vs. price impact. The dashed vertical line indicates the limit of fire sales calculated in the Model section. The full line indicates the baseline value.

entire equity.

For internal purposes, we run the model with a more complex price function that assigns different price impacts to different maturities of the covered bonds, and takes into account sub-market effects for each issuer, dependent on the issuer's size. With this more complex price impact function, we estimate that banks will lose 31 billion DKK, equal to 10 per cent of their equity. After the fire sales, the banks' solvency will be 1 percentage point lower.

\section{Discussion}

The results shown in the previous section rely on a number of assumptions. It is worth looking more closely at some of those assumptions. In particular, we examine assumptions around (i) the shock, (ii) the calibration of the price impact, (iii) the choice of time period, (iv) that banks only sell covered bonds as a result of the shock, 


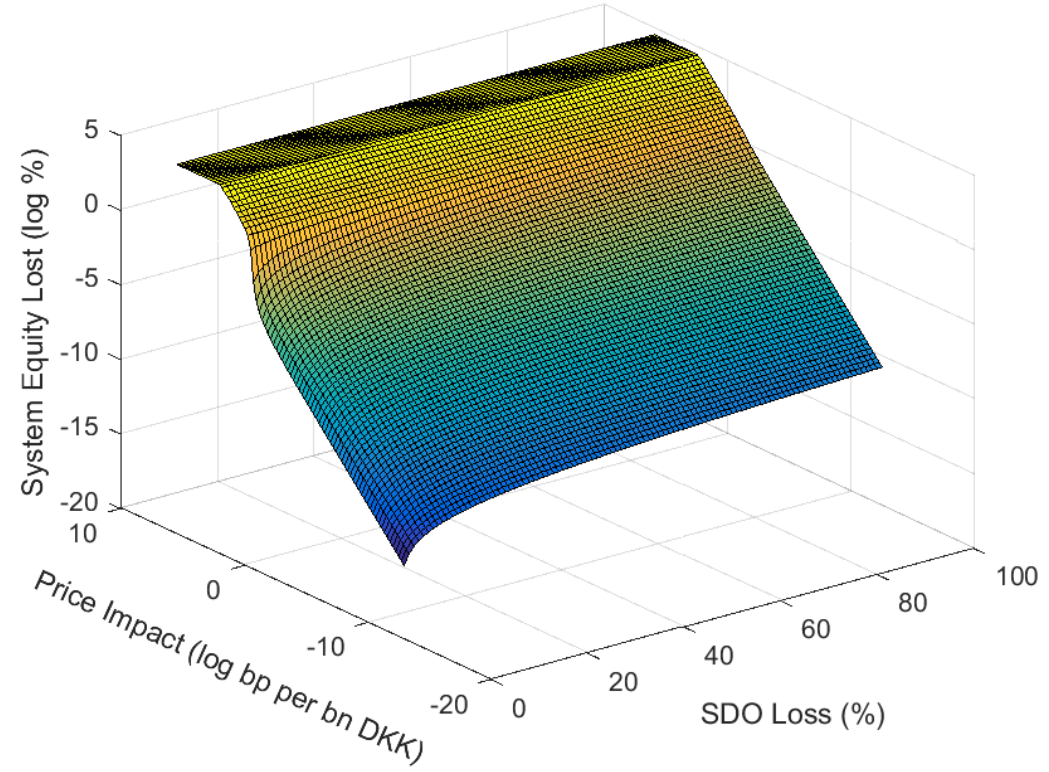

Figure 14: Log percentage system equity lost vs. log price impact with varying size of shock.

and $(\mathrm{v})$ that banks will attempt to return to their previous solvency level.

\section{VI.1. Shock}

In this model, the shock that triggers the fire sale is the loss of CRR compliance for covered bonds. However, similar to that in Greenwood et al. (2015) and Duarte and Eisenbach (2015), the shock that triggers the fire sale could be an asset price fall. If CRR compliant covered bonds were to lose their CRR compliance, it is likely that their price would fall at the same time. However, that is not included in this analysis. As mentioned previously, we separate the loss of compliance from the price fall in covered bonds, so that we can analyse the effects individually. Using such a price fall as the trigger would involve estimating how much the price would fall just from the loss of CRR compliance. While that might be an interesting exercise, the main point of this analysis is to estimate the effects of the fire sale that would follow, and, as we have shown, the fire sale is likely to happen regardless of an initial price 
fall from the loss of CRR compliance, under the assumption that banks attempt to return to their original solvency level. Further in this section we discuss that fire sales may even happen without this assumption.

\section{VI.2. Calibration of the price impact}

The price impact measures how much the price will change for a given volume of sales. The greater the price impact is, the larger the banks' loss of equity will be, and hence the amount of covered bonds, that the banks will need to sell in the next round to return to their previous solvency level, will be greater. Given that banks own a limited amount of covered bonds, at some point they will not be able to sell more bonds if the price impact is greater. Therefore, with a greater price impact, banks will both lose a greater amount of equity through the fire sale and will not be able to improve solvency by further sales. In the baseline model, we use the same price impact that was used by Greenwood et al. (2015) and we use this estimation as a starting point for our analysis. Duarte and Eisenbach (2015) use a price impact

of similar magnitude. Both papers mention the scarce literature on this subject and the difficulty of estimating an appropriate price impact. This is due to both a lack of data and the plethora of variables that can affect it. Nonetheless, there is reason to suspect that in a crisis, such as analysed in this article, the price impact will be stronger than the baseline model.

There are a variety of ways in which one could consider how large the price impact might be in a crisis. One way is to consider the effect on bond yields. Under the baseline model, we can translate the price decrease into a 10 basis point increase in yields on the covered bonds included in the Nykredit market data shown in Figure 15. However, during the financial crisis, the spread on covered bonds increased by 134 basis points (Figure 15). For our model to be able to reach the spread increase recorded during the financial crisis, the price impact would need to be more than 


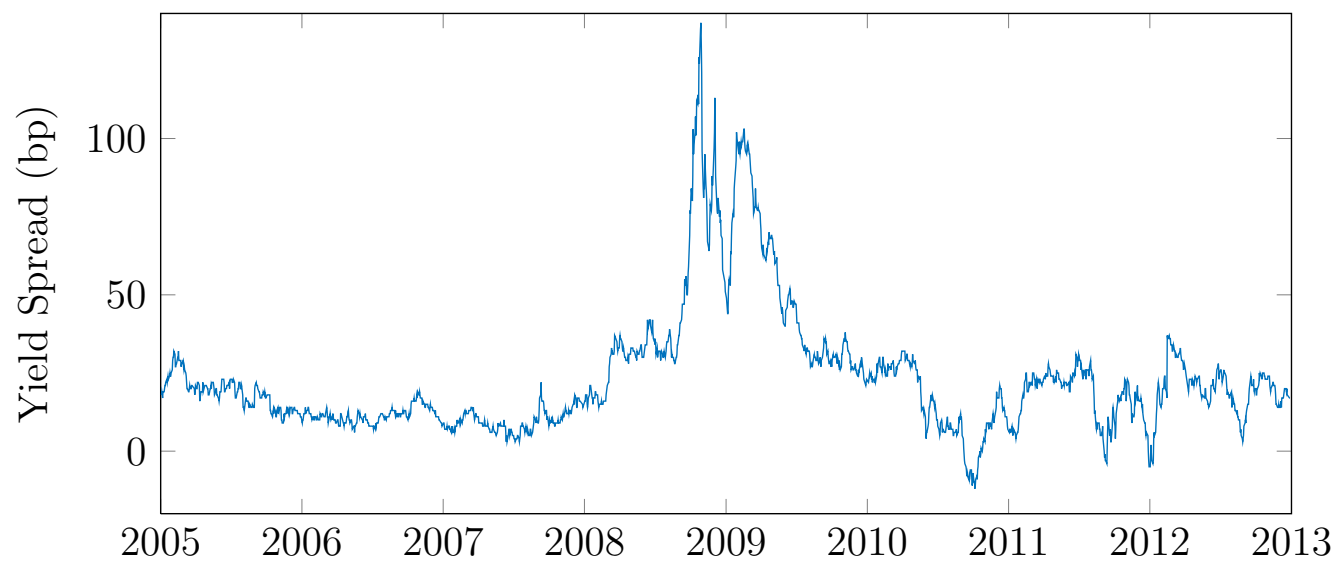

Figure 15: Yield of Danish covered bonds through the financial crisis. The yield increase from the trough in 2007 to the peak during the crisis in 2008 is 134 basis points. The yield is measured by Nykredit's nominally weighted SWAP-OAS spread. Available at: https://www.nykredit.dk/ marketsdk/info/nykreditindeks.xml. [Accessed 21 November 2016].

ten times as large as the baseline Greenwood et al. (2015) value.

Another way to consider how large the price impact would be is to view other estimates, which specifically look at Danish financial instruments. Here we find that the price impact of the baseline case is below those estimated on the Danish financial market. Dick-Nielsen et al. (2012) estimated the price impact of trades on the Danish covered bond market during the 2008 financial crisis. In their study, the median price impact of trades on the short-term covered bond market was around 30 basis points per billion DKK sold during the financial crisis. They also find a price impact of 5 and 162 basis points per billion DKK for the 5th and 95th percentile respectively for short-term covered bonds, showing a large range of possible valid values for this measure. In contrast, Buchholst et al. (2010) estimated the price impact to be between 83 and 141 basis points per billion DKK sold, with a median of 102, for short-term bonds in a paper based on the Danish financial market. Buchholst et al. (2010) studied only one segment of the covered bond market, namely wholesale short-term bullet bonds issued by mortgage banks.

The large differences of the estimates of price impacts in these studies is likely due to whether they were estimated in a crisis and the narrowness of the market segment 
studied. In models in which the price impact is estimated during a crisis, the price impact should be larger than when estimated outside of a crisis (Dick-Nielsen et al. (2012)). Additionally, price impacts estimated for a single asset will be larger than price impacts estimated for the market as a whole. In our baseline model, we use the price impact in a crisis situation and for the Danish covered bond market as a whole, treating each issuer's covered bonds as being essentially identical. Therefore, we would expect an appropriate price impact to be somewhere in between the estimates of Greenwood et al. (2015) and Duarte and Eisenbach (2015) and those of DickNielsen et al. (2012) and Buchholst et al. (2010). Nonetheless, in the sensitivity analysis presented in the Results section, the system equity lost reaches 100 per cent at price impacts significantly lower than those shown in Buchholst et al. (2010). Overall, we would therefore expect the price impact to be large enough to cause explosive fire sales.

It is also assumed here that banks will attempt to return to their previous solvency level as soon as possible, which is discussed further in Subsection VI.5. If, however, banks had a longer time to return to solvency, the price impact is likely to be lower.

\section{VI.3. Choice of time period}

Our analysis was conducted on data from July 2015. Nonetheless, the results are fairly robust to the choice of time period. Under the baseline model, if the loss of CRR compliance had occurred at any time over the past six years, the system equity loss would have been between 1 and 1.5 per cent (Figure 16). While the estimated loss is lower in later time periods, the analysis of the later periods still suggests a significant loss of equity. 


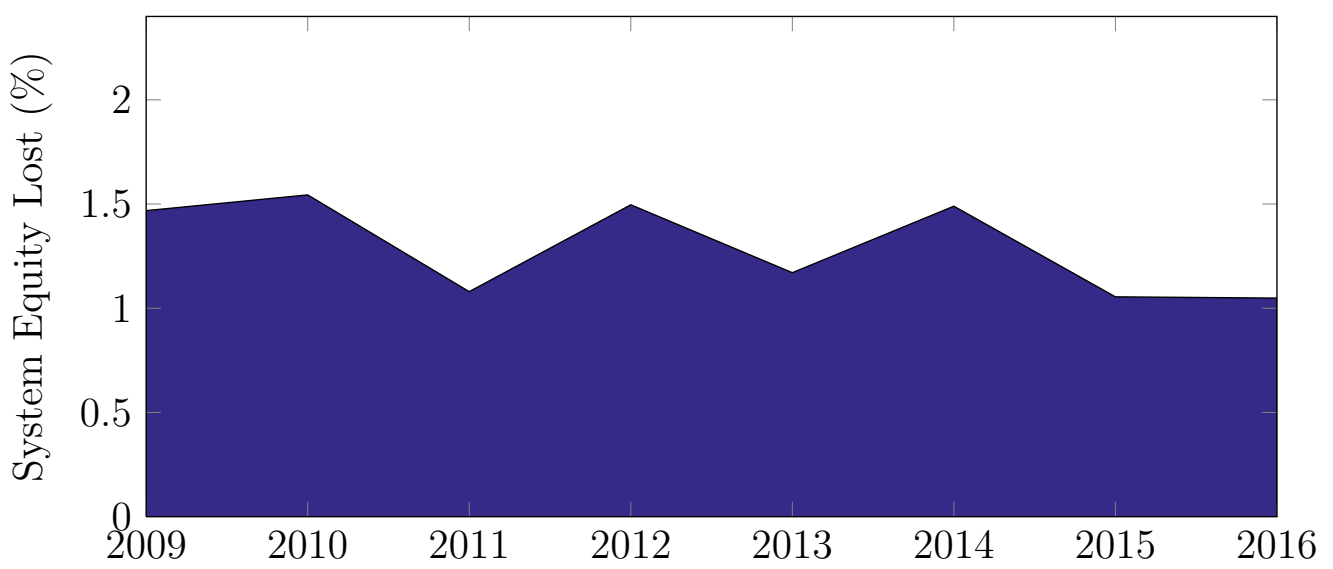

Figure 16: System equity lost had it occured at periods back in time. Accounting equity is used rather than CET1 to make it comparable to before 2014.

\section{VI.4. Selling other assets}

We assume that banks only sell covered bonds to regain their solvency in the face of a shock. Instead they could sell other assets, or a mix of other assets and their covered bonds, to return to their preferred solvency level. By selling other assets, they would reduce the size of the fire sale effect on the covered bond market and so reduce the losses that they would incur.

Banks are, however, rather restricted in which assets they can sell to return to solvency. As solvency levels are measured as a share of risk-weighted assets, banks can only sell those assets that have a risk weight to improve their solvency. This will exclude government bonds from the possible assets to sell. Further, the largest share of banks' assets are loans that they have made to businesses and households, which they generally would not be able to convert to cash quickly enough to use them to meet solvency requirements, and doing so could spill over to the real economy with potentially systemic effects. Other assets that would be possible to sell are banks' investments in equities. In general, these would not be large enough to change the overall results of this study. Therefore, as banks do not seem to own enough other liquid assets, it seems reasonable to assume that the main assets that banks sell to 


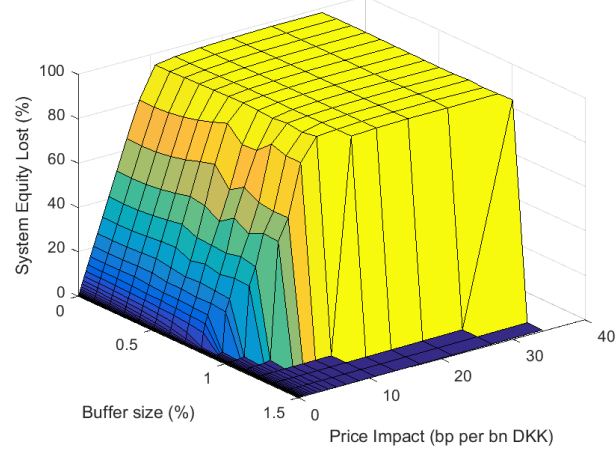

(a) System equity losses

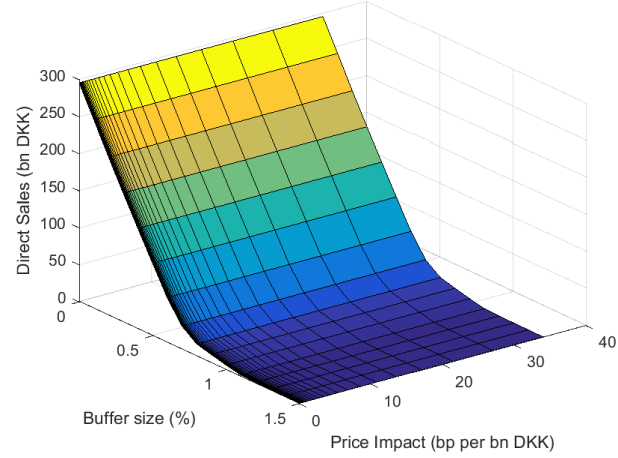

(c) Direct sales

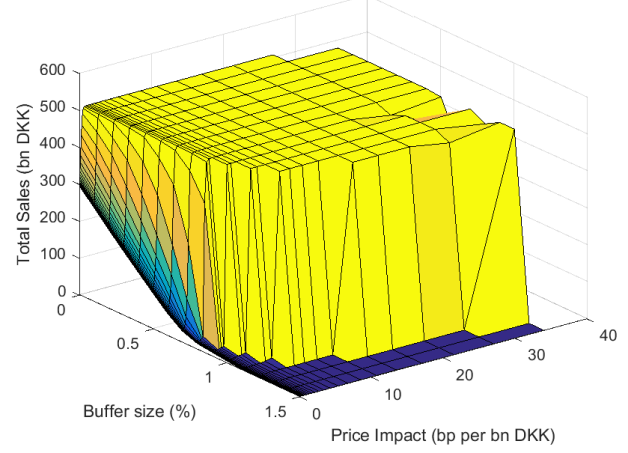

(b) Total sales

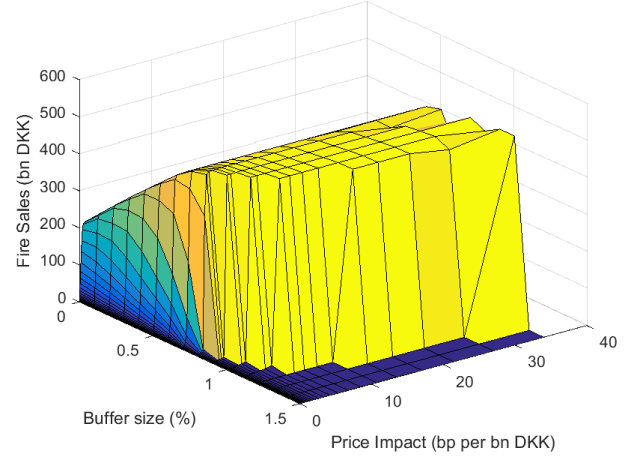

(d) Fire sales

Figure 17: Losses from varying buffer size and price impact, for a CRR compliance loss of 100 per cent.

meet solvency requirements will be their stock of covered bonds.

Alternatively, banks could raise additional capital to regain their solvency. While this could be a long-term solution for bank's in the face of such a shock, we however consider that, as seen from the shareholders of an individual banks perspective, it would probably be more attractive to sell covered bonds than to issue new equity in the middle of such a crisis. 


\section{VI.5. Return to solvency}

In this paper, we have assumed that, following a shock, banks will attempt to return to the level of solvency that they had before the shock occurred. This is a standard assumption in the fire sale literature (See for example Greenwood et al., 2015; Cecchetti et al., 2016; Duarte and Eisenbach, 2015). Nonetheless, banks, in general, tend to have solvency levels greater than the minimum required by banking regulations. Therefore, they do have some flexibility to reduce their solvency levels somewhat and still comply with the regulations.

However, in a situation such as described in this model it may not be a bad assumption that they return to their previous level of solvency, as the developments in the economy, which lead to the covered bonds losing their CRR compliance, are likely to have reduced the banks' buffers.

Given the size of the losses that banks would incur through attempting to return to their previous solvency levels, alternative courses of action might be attractive to the banks as a whole and the prudential authorities. If banks had a reasonable buffer above the regulatory requirements and were willing to use this buffer to cushion the impact of the loss of CRR compliance, or, alternatively, the authorities allowed banks to let their solvency levels fall temporarily, banks might be able to avoid the fire sales shown in the previous sections.

In the model, if the buffer size is greater than 1.5 per cent, then any level of price impact and shock size can be accommodated because the banks do not enter into such explosive fire sales (Figure 17(a)).

However, for the buffer to work, it has to be such that the banks avoid any direct sales following the change in risk weights (Figure 17(b, c and d)). In practice, even if banks do not react to the initial solvency drop from the effects on risk weights, they might still need to sell assets because regulations with regard to large exposures would begin to bind. Thus a large sell-off could still occur, and comparable losses 
would consequently be incurred. Moreover, in the initial phase, the price of covered bonds that lost their compliance are likely to fall even without direct sales, as the loss of CRR compliance will probably be interpreted as an increase in the risk of such securities. This would have a similar effect as a direct sale, and could in itself lead to an explosive fire sale. This effect has not been included in the results shown in Figure 17(a), and so equity losses and a fire sale could in effect also appear for large buffers.

\section{Conclusion}

In this paper, we study the impacts of fire sales that result from banks responding

to a shock to their covered bond exposures. Specifically, we adapt the Greenwood et al. (2015) fire sale model to a situation in which Danish CRR compliant covered bonds lose their CRR compliance, and become non-CRR compliant covered bonds. This loss entails a loss of certain regulatory advantages for the owners of the bonds, such as lower risk weights. The direct effect of the shock is that banks' solvency decreases. We model a possible outcome to the loss of CRR compliance, namely that this might cause banks to sell their covered bond holdings in a fire sale to return to their initial solvency levels. These sales of covered bonds lead to the indirect effect, which is a fall in the price of covered bonds. The price fall leads to a loss of equity for all banks that own covered bonds. The indirect effect induces additional fire sales, which cause further losses of equity. This continues until banks return to their original solvency, run out of bonds or lose all their equity.

We find that if the price effect is above a threshold level, explosive fire sales occur in which banks end up selling all of their holdings of covered bonds. To our knowledge, this is the first time such a threshold has been shown. Furthermore, once the explosive fire sales begin, the size of the initial shock is unimportant for the final 
result. In the model one way for banks to avoid the explosive fire sale spiral is to have a solvency buffer of around 1.5 per cent to avoid fire sales due to falling solvency, regardless of the price impact and size of shock. In practice, however, banks' buffers may not be as large at the time of such a shock, and even with a large buffer, fire sales might be caused by other regulatory concerns such as those with regard to large exposures, or by a direct price fall from the loss of CRR compliance, which could happen regardless of the initial sales. This could in turn lead to equity losses and fire sales despite any buffers the banks might currently have.

Within this analysis we have only considered the actions of banks in response to the loss of CRR compliance for covered bonds. The reactions of other significant financial market participants, such as foreign investors and pension funds might have significant effects on the outcomes in an actual crisis situation. Implicitly we assume that other financial market participants would be buying the covered bonds that the banks are selling through fire sales. However, it is possible that other participants are not willing, or able, to do so. Further research might be able to highlight whether these other participants are likely to mitigate or amplify the shocks analysed in this paper. Nonetheless, given the size of the banking sector we believe that we have captured some important effects of such a shock.

\section{References}

Bindseil, U.

2013. Central bank collateral, asset fire sales, regulation and liquidity. ECB Working Paper no. 1610.

Buchholst, B. V., J. Gyntelberg, and T. Sangill

2010. Liquidity of Danish government and covered bonds - before, during and 
after the financial crisis - preliminary findings. Danmarks Nationalbank Working Paper no. 70.

Caballero, R. J. and A. Simsek

2013. Fire sales in a model of complexity. The Journal of Finance, 68(6):25492587.

Cecchetti, S., M. Rocco, and L. Sigalotti

2016. Contagion and fire sales in banking networks. Bank of Italy Temi di Discussione (Working Paper) no. 1050.

Cruz Lopez, J., R. Mendes, and H. Vikstedt

2013. The market for collateral: The potential impact of financial regulation. Bank of Canada Financial System Review.

Danmarks Nationalbank

2016, 2nd Half. Developments and trends. In Financial Stability.

Dick-Nielsen, J., J. Gyntelberg, and T. Sangill

2012. Liquidity in government versus covered bond markets. Danmarks Nationalbank Working Paper no. 83.

Dow, J. and J. Han

2015. The paradox of financial fire sales and the role of arbitrage capital. Swedish House of Finance Research Paper no. 15-10.

Duarte, F. and T. M. Eisenbach

2015. Fire-sale spillovers and systemic risk. Federal Reserve Bank of New York no. 645 .

Gorton, G. 
2009. Information, liquidity, and the (ongoing) panic of 2007. American Economic Review, 99(2):567-72.

Greenwood, R., A. Landier, and D. Thesmar

2015. Vulnerable banks. Journal of Financial Economics, 115(3):471-485.

Hart, O. and J. Moore

1994. A theory of debt based on the inalienability of human capital. The Quarterly Journal of Economics, 109(4):841-879.

Hart, O. and J. Moore

1995. Debt and seniority: An analysis of the role of hard claims in constraining management. American Economic Review, 85(3):567-85.

Hart, O. and J. Moore

1998. Default and renegotiation: A dynamic model of debt. The Quarterly Journal of Economics, 113(1):1-41.

IMF

2012. Safe assets: Financial system cornerstone? In IMF Global Stability Report: The Quest for Lasting Stability.

Shleifer, A. and R. W. Vishny

2010. Fire sales in finance and macroeconomics. NBER Working Paper no. 16642, National Bureau of Economic Research.

Silva, T. C., M. A. da Silva, and B. M. Tabak

2016. Modeling financial networks: A feedback approach. Banco Central do Brasil Working Paper no. 438. 